\title{
Removal Site Evaluation Report on the Bulk Shielding Facility at Oak Ridge National Laboratory, Oak Ridge, Tennessee
}
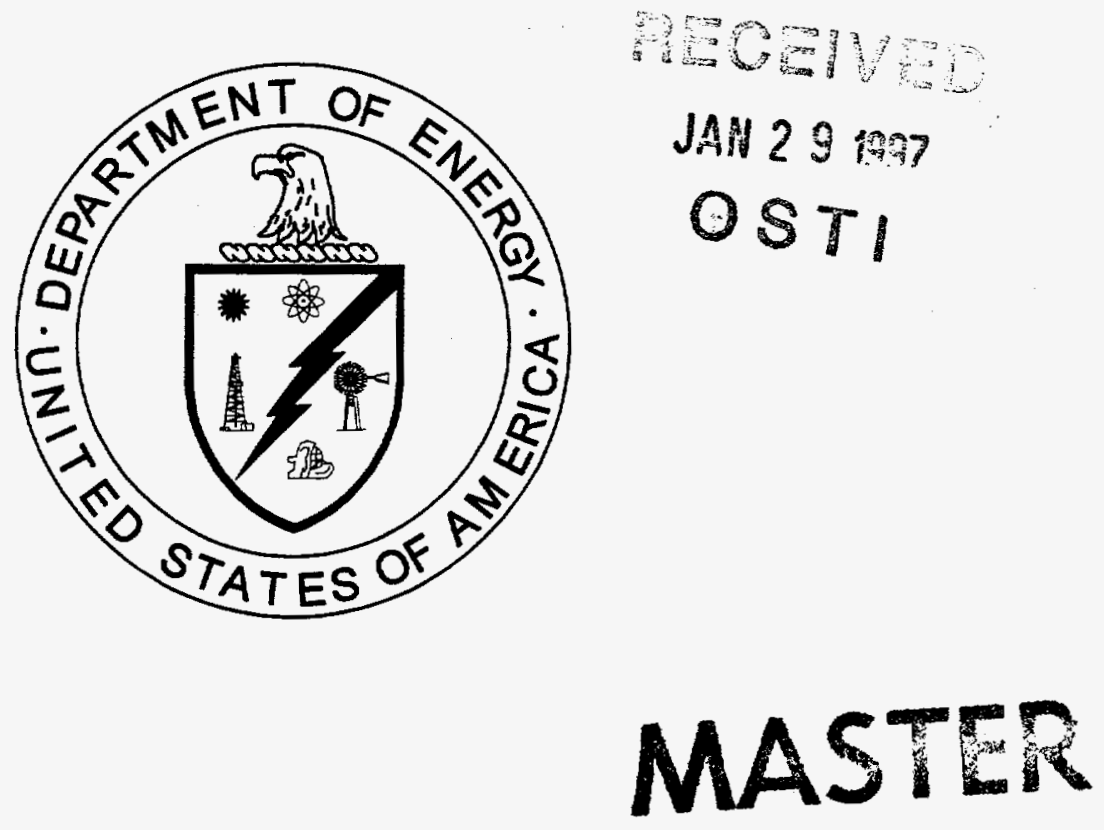

This document has been approved by the ORNL Technical Information Office for release to the public. Date: $9 / 13 / 94$ 


\section{Advanced Sciences, Inc.}

contributed to the preparation of this document and should not be considered an eligible contractor for its review.

This report has been reproduced directly from the best available copy.

Available to DOE and DOE contractors from the Office of Scientific and Technical Information, P.O. Box 62, Oak Ridge, TN 37831; prices available from 423-576-8401 (fax 423-576-2865).

Available to the public from the National Technical Information Service, U.S. Department of Commerce, 5285 Port Royal Rd., Springfield, VA 22161. 


\section{DISCLAIMER}

This report was prepared as an account of work sponsored by an agency of the United States Government. Neither the United States Government nor any agency thereof, nor any of their employees, makes any warranty, express or implied, or assumes any legal liability or responsibility for the accuracy, completeness, or usefulness of any information, apparatus, product, or process disclosed, or represents that its use would not infringe privately owned rights. Reference herein to any specific commercial product, process, or service by trade name, trademark, manufacturer, or otherwise does not necessarily constitute or imply its endorsement, recommendation, or favoring by the United States Government or any agency thereof. The views and opinions of authors expressed herein do not necessarily state or reflect those of the United States Government or any agency thereof. 


\section{DISCLAMMER}

Portions of this document may be illegible in electronic image products. Images are produced from the best available original document. 


\author{
Energy Systems Environmental Restoration Program \\ Removal Site Evaluation Report \\ on the Bulk Shielding Facility \\ at Oak Ridge National Laboratory, \\ Oak Ridge, Tennessee
}

Date Issued-September 1996

\author{
Prepared by \\ Advanced Sciences, Inc. \\ Oak Ridge, Tennessee \\ under subcontract 96B-99311C \\ Prepared for the \\ U.S. Department of Energy \\ Office of Environmental Management \\ under budget and reporting code EW 70 \\ Environmental Management Activities at \\ OAK RIDGE NATIONAL LABORATORY \\ Oak Ridge, Tennessee 37831-6285 \\ managed by \\ LOCKHEED MARTIN ENERGY SYSTEMS, INC. \\ for the \\ U.S. DEPARTMENT OF ENERGY \\ under contract DE-AC05-84OR21400
}




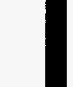

.
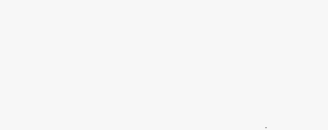

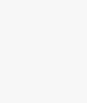

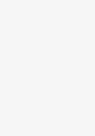

.
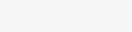

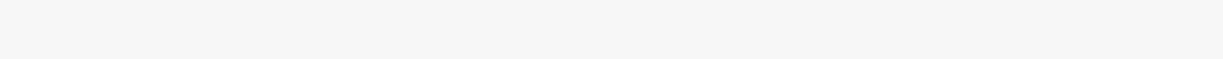

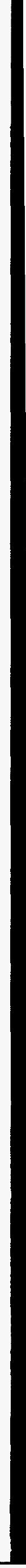

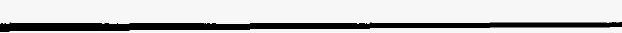




\section{PREFACE}

This document, Removal Site Evaluation Report on the Bulk Shielding Facility at Oak Ridge National Laboratory, Oak Ridge, Tennessee (DOE/OR/01-1516\&D1), constitutes the final phase II remedial site evaluation of the Bulk Shielding Facility and was prepared in accordance with requirements under the Comprehensive Environmental Response, Compensation, and Liability Act of 1980. This work was performed under Work Breakdown Structure 1.6.6.2.1, "Oak Ridge Reservation," and Activity Data Sheet Number OR6500FT, "Oak Ridge Reservation Facility Transition Program." Publication of this document provides the Environmental Restoration Program with information necessary to evaluate whether hazardous and/or radiological contaminants in and around the Bulk Shielding Facility pose a substantial risk to human health or the environment and if remedial site evaluations or removal actions are required. 


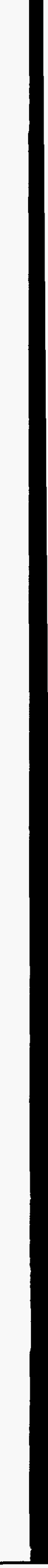




\section{CONTENTS}

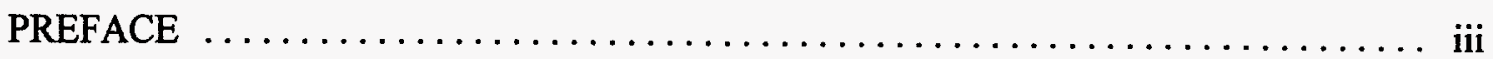

FIGURES $\ldots \ldots \ldots \ldots \ldots \ldots \ldots \ldots \ldots \ldots \ldots \ldots \ldots \ldots \ldots \ldots \ldots \ldots \ldots \ldots$ vii

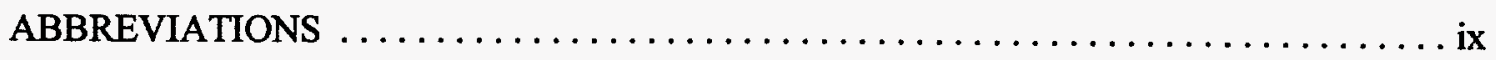

EXECUTIVE SUMMARY $\ldots \ldots \ldots \ldots \ldots \ldots \ldots \ldots \ldots \ldots \ldots \ldots \ldots \ldots \ldots \ldots \ldots$

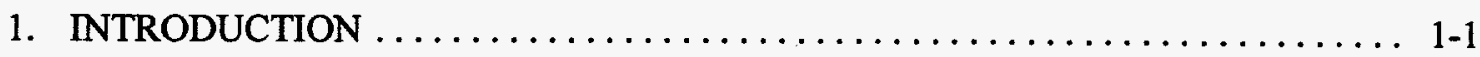

2. SUMMARY OF REMOVAL SITE EVALUATIONS $\ldots \ldots \ldots \ldots \ldots \ldots \ldots \ldots$.

2.1 BUILDING 3004-WATER DEMINERALIZER FACILITY . . . . . . . . . 2-1

2.2 BUILDING 3009-BULK SHIELDING FACILITY PUMPHOUSE $\ldots \ldots \ldots$ 2-1

2.3 BUILDING 3010 - BULK SHIELDING REACTOR FACILITY $\ldots \ldots \ldots \ldots . .2-2$

2.4 BUILDING 3088-BULK SHIELDING FACILITY

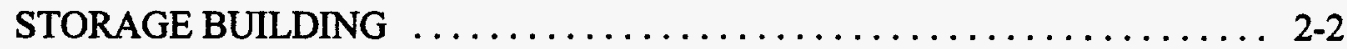

2.5 BUILDING 3098-BULK SHIELDING FACILITY FILTER HOUSE . . . . . 2 2-2

2.6 BUILDING 3101-BULK SHIELDING FACILITY

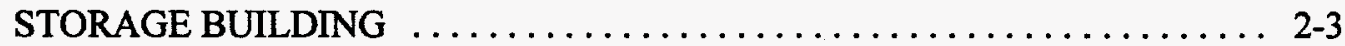

2.7 BUILDING 3117-BULK SHIELDING FACILITY COOLING TOWER $\ldots \ldots$ 2-3

2.8 BUILDING 3119-BULK SHIELDING REACTOR HEAT

EXCHANGER AND PUMPHOUSE ...................... 2-4

2.9 TANKS A-1204 AND 13822-LOW TEMPERATURE NEUTRON

IRRADIATION FACILITY REFRIGERANT TANKS $\ldots \ldots \ldots \ldots \ldots \ldots \ldots . . \ldots 2-4$

2.10 STATUS OF REMOVAL SITE EVALUATIONS $\ldots \ldots \ldots \ldots \ldots \ldots \ldots \ldots$.

3. BUILDING 3004 INFORMATION FORM $\ldots \ldots \ldots \ldots \ldots \ldots \ldots \ldots \ldots \ldots \ldots \ldots$

4. BUILDING 3009 INFORMATION FORM $\ldots \ldots \ldots \ldots \ldots \ldots \ldots \ldots \ldots \ldots \ldots$

5. BUILDING 3010 INFORMATION FORM $\ldots \ldots \ldots \ldots \ldots \ldots \ldots \ldots \ldots \ldots \ldots$

6. BUILDING 3088 INFORMATION FORM $\ldots \ldots \ldots \ldots \ldots \ldots \ldots \ldots \ldots \ldots \ldots \ldots$

7. BUILDING 3098 INFORMATION FORM $\ldots \ldots \ldots \ldots \ldots \ldots \ldots \ldots \ldots \ldots \ldots$

8. BUILDING 3101 INFORMATION FORM $\ldots \ldots \ldots \ldots \ldots \ldots \ldots \ldots \ldots \ldots \ldots$

9. BUILDING 3117 INFORMATION FORM $\ldots \ldots \ldots \ldots \ldots \ldots \ldots \ldots \ldots \ldots \ldots$ 
11. TANKS A-1204 AND 13822 INFORMATION FORM ................ 11-1 


\section{FIGURES}

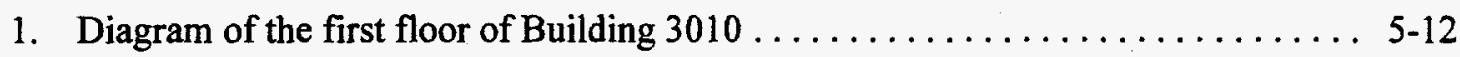

2. Diagram of the second floor of Building $3010 \ldots \ldots \ldots \ldots \ldots \ldots \ldots \ldots \ldots \ldots \ldots \ldots \ldots \ldots, 13$ 


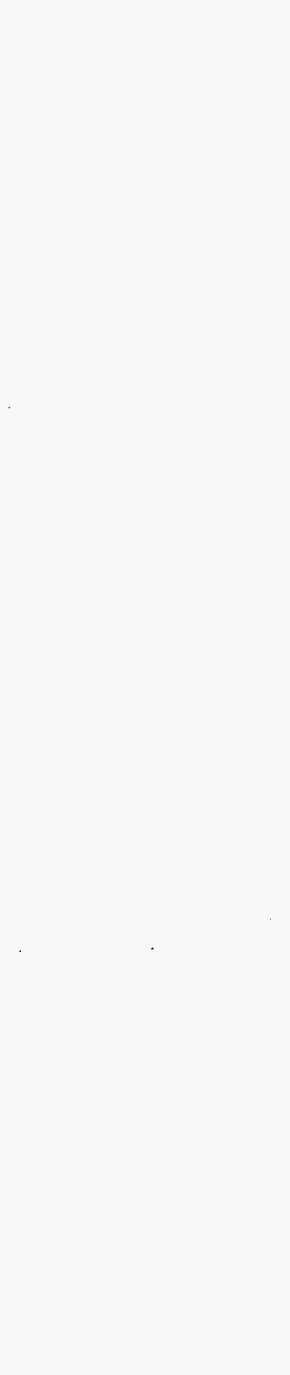




\section{ABBREVIATIONS}

ACM

BSF

BSR

$C F R$

D\&D

ER

HAZMAT

HEPA

HRFDP

LBP

LLLW

LTNIF

LMES

MTR

ORNL

ORR

PCA

PCB

RAD

RCRA

RmSE

RSE

S\&M

TCLP

TSF

WAG

WOC asbestos-containing material

Bulk Shielding Facility

Bulk Shielding Reactor

Code of Federal Regulations

Decontamination and Decommissioning

Environmental Restoration (Program)

hazardous material

high-efficiency particulate air (filter)

High Ranking Facilities Deactivation Project

lead-based paint

liquid low-level (radioactive) waste

Low Temperature Neutron Irradiation Facility

Lockheed Martin Energy Systems, Inc.

Metals Testing Reactor

Oak Ridge National Laboratory

Oak Ridge Reservation

pool critical assembly

polychlorinated biphenyl

radiologic

Resource Conservation and Recovery Act

removal site evaluation

remedial site evaluation

surveillance and maintenance

Toxicity Characteristic Leaching Procedure

Tower Shielding Facility

waste area grouping

White Oak Creek 


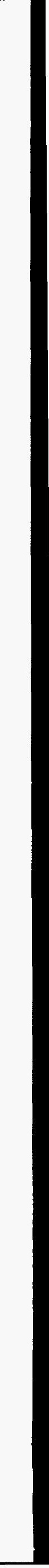




\section{EXECUTIVE SUMMARY}

This removal site evaluation report on the Bulk Shielding Facility (BSF) at Oak Ridge National Laboratory was prepared to provide the Environmental Restoration Program with information necessary to evaluate whether hazardous and/or radiological contaminants in and around BSF buildings pose a substantial risk to human health or the environment (i.e., a high probability of adverse effects) and whether remedial site evaluations or removal actions are, therefore, required. A removal site evaluation was conducted at nine areas associated with the BSF. The scope of each evaluation included (1) a search for, and review of, readily available historical records regarding operations and use of the facility (including hazardous substance usage and existing contamination); (2) interviews with facility personnel concerning current and past practices; and (3) a brief walkthrough to visually inspect the facility and identify existing hazard areas requiring maintenance actions or remedial evaluation.

The results of the removal site evaluation indicate that no substantial risks exist from contaminants present because adequate efforts are being made to contain and control existing contamination and hazardous substances and to protect human health and the environment.

At Building 3004, deteriorated and peeling exterior paint has a direct pathway to the storm water drainage system and can potentially impact local surface water during periods of storm water runoff. The paint is assumed to be lead based, thus posing a potential problem. The paint should be sampled and analyzed to determine its lead content and to assess whether a hazard exists. If so, a maintenance action will be necessary to prevent further deterioration and dislodging of the paint. In addition, if the paint contains lead, then a remedial site evaluation should be conducted to determine whether lead from fallen chips has impacted soils in the immediate area of the building.

The recommended corrective action for Building 3004 is being conducted as a maintenance action. Given the current conditions and status of the BSF buildings, these removal site evaluations are considered complete and terminated. 


\section{INTRODUCTION}

A removal site evaluation is required by the regulators for all facilities in the Nuclear Material and Facility Stabilization (EM-60) Program included in Appendix C of the Federal Facility Agreement. Between May 29 and June 17, 1996, removal site evaluations were conducted at the Bulk Shielding Facility (BSF) buildings at Oak Ridge National Laboratory (ORNL). The scope of the evaluations included (1) a search for, and review of, readily available historical records regarding operations and use of the facility (including hazardous substance usage and existing contamination); (2) interviews with facility personnel concerning current and past practices; and (3) a brief walkthrough to visually inspect the facility and identify existing hazard areas requiring maintenance actions or remedial evaluation. The results of the removal site evaluations are summarized in Sect. 2, and the completed information forms are presented in Sects. 3-11. 


\section{SUMMARY OF REMOVAL SITE EVALUATIONS}

\subsection{BUILDING 3004 (INCLUDING TANKS 3004A, B, C, D, F, AND H)- WATER DEMINERALIZER FACHLITY}

Building 3004 has been partially deactivated. The building continues to provide purified water both directly and indirectly to various ORNL facilities while awaiting entry into the Decontamination and Decommissioning (D\&D) Program. The only operations currently ongoing in this building are water purification, surveillance and maintenance (S\&M), and deactivation activities. The original water demineralizing system has been deactivated, and the associated tanks (Tanks 3004A, B, C, D, F, and H) remain empty. The building is accessed periodically by maintenance personnel in order to conduct various maintenance activities on active and inactive equipment; otherwise, the building remains secured from public access.

Because of access policies associated with Building 3004, the building could not be accessed for inspection. As a result, facility personnel were interviewed, and photographs of the interior of the building were observed in lieu of a visual inspection of the building. During the evaluation, no imminent hazard areas requiring maintenance actions were identified inside Building $\mathbf{3 0 0 4}$ or in association with the deactivated tanks. Radiologic (RAD) hazard areas, asbestos-containing materials (ACMs), and inactive tanks are marked and isolated as necessary to ensure worker safety and to prevent inadvertent release within the facility. In addition, a combination of engineering and administrative controls are in place and enforced for activities within the building for worker and environmental protection. Current actions that are taken to prevent further release of contamination and to ensure worker safety within Building 3004 are considered adequate until D\&D activities begin.

One external imminent hazard area, however, was identified in association with Building 3004 . On the basis of the age of the facility, the ORNL Lead Management Program assumes that the paint on the building contains lead. Exterior paint over the entire surface area of the building is badly deteriorated and peeling off. The apron around the building consists of both paved and soil areas. Storm drains are located along the east and west sides of the building. Paint chips that fall off the building have a direct pathway to the storm water drainage system during a rain event. This poses a potential for direct impact to surface water in the local area during times of storm water runoff. The paint on this building should be sampled and analyzed for lead content to determine if, in fact, a hazard exists. If a hazard does exist, a maintenance action will be necessary to prevent further deterioration and dislodging of the paint. In addition, if the paint is found to contain lead, a remedial site evaluation should be conducted to determine whether lead from fallen paint chips has impacted the soil in the immediate area of Building 3004.

\subsection{BUILDING 3009-BULK SHIELDING FACILITY PUMPHOUSE}

Building 3009 currently is in an inactive, standby mode, awaiting entry into the D\&D Program. No current operations, other than S\&M and deactivation activities, are ongoing in this building. This building currently is unoccupied and remains locked.

During the evaluation, no imminent hazard areas requiring maintenance actions were identified in association with Building 3009. Because of residual RAD surface contamination on walls and 
equipment, the building is posted as radiologically contaminated to ensure worker safety and to prevent inadvertent release within the facility. However, the interior of the building was being painted and cleaned at the time of the remedial site evaluation, and facility personnel indicated that its radiologic status is likely to change as a result. Current actions taken to prevent further release of contamination and ensure worker safety within Building 3009 are considered adequate until D\&D activities begin.

\subsection{BUILDING 3010—BULK SHIELDING REACTOR FACILITY}

Building 3010 is the main reactor building at the BSF and is currently in an inactive, standby mode, awaiting entry into the D\&D Program. No current operations, other than S\&M and deactivation activities, are ongoing in this building. The building is occupied by approximately six personnel who are responsible for conducting various S\&M and deactivation activities.

During the evaluation, no imminent hazard areas requiring maintenance actions were identified in association with Building 3010. Radiologic hazard areas and ACMs are marked and isolated as necessary to ensure worker safety and to prevent inadvertent release within the facility. In addition, engineering and administrative controls are in place and enforced within the facility for worker and environmental protection. Current actions that are taken to prevent further release of contamination and to ensure worker safety within Building 3010 are considered adequate until D\&D activities begin.

\subsection{BUILDING 3088-BULK SHIELDING FACILITY STORAGE BULDING}

Building 3088 is currently in an inactive, standby mode, awaiting entry into the D\&D Program. No current operations, other than minimal S\&M activities, are ongoing in this building. The building is unoccupied and remains locked.

During the evaluation, no imminent hazard areas requiring maintenance actions were identified in association with Building 3088. No RAD hazard areas or hazardous substances/materials were identified in connection with this building other than potential lead-based paint (LBP) on the exterior surfaces. Current actions that are taken to maintain Building 3088 are considered adequate until D\&D activities begin.

It should be noted that if the paint associated with this building is found not to contain lead, Building 3088 would be suitable for a No Further Investigation Determination in accordance with the guidelines set forth in ES/ER/TM-161, Rev. 0, "Site Evaluation Process for the DOE-ORO Environmental Restoration Program."

\subsection{BULDING 3098-BULK SHIELDING FACILITY FILTER HOUSE}

Building 3098 remains active in support of BSF ventilation needs while awaiting entry into the D\&D Program. The building houses a high efficiency particulate air (HEPA) filter bank, is unoccupied, and remains locked. 
During the evaluation, no imminent hazard areas requiring maintenance actions were identified in association with Building 3098 . There was, however, some confusion over the extent of residual RAD surface contamination in the building. Information provided in the EM60 Surplus Facility Inventory and Assessment Database and the High Ranking Facilities Deactivation Project (HRFDP) Work Plan indicated that $75 \%$ of the building was contaminated, including wall/floor surfaces and internal surfaces of ventilation equipment. However, no RAD warning postings or labels were observed during inspection of the building. Facility personnel indicated that the only RAD contamination they were aware of was internal to the ventilation equipment. No RAD data were identified to verify the extent of contamination during the removal site evaluation. The extent of RAD contamination should be verified in this building and subsequently labeled as appropriate. If there is no RAD contamination external to the ventilation ducts and equipment, the database and work plan should be corrected to accurately reflect current conditions. This situation does not present an imminent hazard Because the building remains locked and is only accessed occasionally to monitor and change the HEPA filters. With the exception of RAD contamination labeling in the building, current actions that are taken to maintain Building 3098 are considered adequate until D\&D activities begin.

\subsection{BUILDING 3101-BULK SHIELDING FACILITY STORAGE BUILDING}

Building 3101 is currently used to store miscellaneous equipment at the BSF until transfer into the D\&D Program. The storage room portion of the building is unoccupied and remains locked.

During the evaluation, no imminent hazard areas requiring maintenance actions were identified in association with Building 3101. RAD hazard areas are marked as necessary to ensure worker safety and to prevent an inadvertent release of contamination. In addition, administrative controls for entry and use of the building are in place and enforced for worker and environmental protection. Current actions that are taken to prevent further release of contamination and ensure worker safety within Building 3101 are considered adequate until D\&D activities begin.

\subsection{BULLDING 3117 (INCLUDING TANK 3117A)-BULK SHIELDING FACILITY COOLING TOWER}

Building 3117 is a cooling tower that currently provides chilled water to air conditioning units at the BSF. Tank $3117 \mathrm{~A}$ is an empty, inactive tank located adjacent to the cooling tower.

During the evaluation, no imminent hazard areas requiring maintenance actions were identified in association with Building 3117 or Tank 3117A. No RAD hazard areas were identified in connection with either structure. The cooling tower contains ACM and chromate-treated lumber; however, neither material represents an immediate hazard. The tank was used to store sulfuric acid that has been removed, and it is currently posted as empty and inactive. There remains the potential for residual chemical contamination within the tank. Current actions that are taken to prevent potential release of contamination, ensure worker safety, and maintain Building 3117 and Tank $3117 \mathrm{~A}$ are considered adequate until $\mathrm{D} \& \mathrm{D}$ activities begin. 


\subsection{BUILDING 3119-BULK SHIELDING REACTOR HEAT EXCHANGER AND PUMPHOUSE}

Building 3119 contains a heat exchanger and pumping equipment that was part of the reactor bay pool cooling system. The equipment has been shutdown and the building is currently in an inactive, standby mode, awaiting entry into the D\&D Program. No current operations, other than S\&M and deactivation activities, are ongoing in this building. The building is not occupied and remains locked.

During the evaluation, no imminent hazard areas requiring maintenance actions were identified in association with Building 3119. RAD hazard areas and ACMs are marked and isolated as necessary to ensure worker safety and to prevent inadvertent release within the facility. In addition, engineering and administrative controls are in place and enforced for worker and environmental protection in the building. Current actions that are taken to prevent further release of contamination and ensure worker safety within Building 3119 are considered adequate until D\&D activities begin.

\subsection{TANKS A-1204 AND 13822-LOW TEMPERATURE NEUTRON IRRADIATION FACILITY REFRIGERANT TANKS}

Cryogenic tanks A-1204 and 13822 were installed at the BSF during the mid-1980s to support the Low Temperature Neutron Irradiation Facility (LTNIF), which is no longer active. Tank A-1204 was used to store $500 \mathrm{gal}$ of liquid nitrogen, and Tank 13822 was used to store 700 gal of liquid helium. These tanks are currently inactive and empty. No potential threats to human health and/or the environment were identified in association with these tanks. The tanks are painted; on the basis of the dates of installation, it is unlikely that the paint contains lead.

As a result of this removal site evaluation, it is recommended that samples of the paint on each tank be taken to confirm the absence of lead. Subsequent to sample analysis, it is further recommended that a No Further Investigation Determination be pursued for these two tanks in accordance with the guidelines set forth in ES/ER/TM-161, Rev. 0, "Site Evaluation Process for the DOE-ORO Environmental Restoration Program."

\subsection{STATUS OF REMOVAL SITE EVALUATIONS}

Given the current conditions and status of the buildings, these removal site evaluations are considered complete and terminated according to the requirements for removal site evaluation termination set forth in 40 CFR 300.410(e). 


\section{BUILDING 3004 INFORMATION FORM}




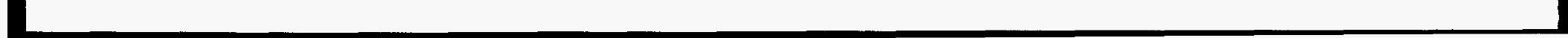


ORNL FACILITY RmSE INFORMATION FORM

\begin{tabular}{|c|c|c|}
\hline \multicolumn{3}{|c|}{ General Information } \\
\hline \multicolumn{3}{|c|}{ 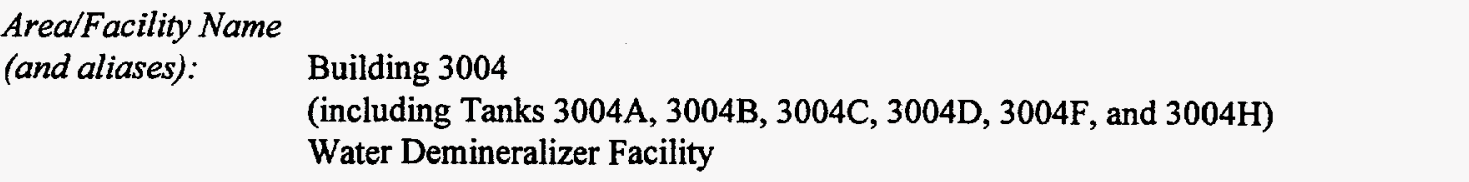 } \\
\hline \multicolumn{3}{|c|}{$\begin{array}{ll}\text { Organization responsible for arealfacility } & \\
\text { (include specific person and phone number if possible): } & \text { K. Constant (241-3146), } \\
& \text { HRFDP Project Manager, } \\
& \text { ER Program, LMES }\end{array}$} \\
\hline Status (active/inactiv & $\begin{array}{l}\text { Fe): Facility is partially active. Tanks are } \\
\text { inactive. }\end{array}$ & Years of Operation: $\approx 44$ \\
\hline \multicolumn{3}{|c|}{$\begin{array}{l}\text { Description of operation: } \\
\text { Building } 3004 \text { provides pure water directly to Buildings } 3010,3001,3002,3042 \text {, and by tanker truck to } \\
\text { Building } 7702 \text { at the Tower Shielding Facility (TSF). The original water treatment system has been replaced } \\
\text { by a mixed resin bed system, and the associated process equipment (caustic and acid tanks, ion columns, } \\
\text { etc.) remains inactive within the building. Treatment equipment is located on the first floor of the building, } \\
\text { and treated water is pumped to a 10,000 gallon holding tank on the fourth floor. Rooms on the upper floors } \\
\text { of the building (second and third floors) were historically used to support laboratory operations; however, } \\
\text { these areas have been taken out of service and any equipment has reportedly been removed from them. }\end{array}$} \\
\hline \multicolumn{3}{|c|}{$\begin{array}{l}\text { Physical description of area/facility: } \\
\text { Access to Building } 3004 \text { is restricted due to its radiological status and was not accessible for visual } \\
\text { inspection during this RmSE. Information on current interior conditions is based on available } \\
\text { photographs of the building and facility personnel interviews. } \\
\text { - Building } 3004 \text { is a four-story, wooden framed building with wooden siding consisting of approximately } \\
1,600 \text { sq. } \mathrm{ft} \text { of floor space. } \\
\text { The building is located in an industrial area of the Main Plant at ORNL approximately } 150 \text { feet west } \\
\text { of Building } 3010 \text {. } \\
\text { Paint on exterior surfaces of the building is in poor condition. } \\
\text { Systems which remain operational within the building include; electrical, fire protection, steam, and } \\
\text { water purification systems. } \\
\text { The immediate area surrounding Building } 3004 \text { is paved to the east and north. The apron to the west } \\
\text { is soil and vegetation. Building } 3005 \text { is located to the south. } \\
\text { Building } 3004 \text { currently contains active and inactive water purification equipment on the first floor, and } \\
\text { a } 10,000 \text { gallon holding tank on the fourth floor. There is also a } 12,000 \text { gallon stainless steel waste } \\
\text { collection tank within the building which is used to collect water from two sumps associated with the } \\
\text { demineralizer. The building also contains the following inactive tanks, which remain empty in the } \\
\text { building (all other nonessential equipment has been removed from the building): }\end{array}$} \\
\hline
\end{tabular}


Physical description of arealfacility (continued):

3004A - 500 gallon, single lined carbon steel caustic tank. Tank was used to mix sodium

hydroxide solutions during the water treatment process.

water treatment process.

$3004 \mathrm{C}$ - $\quad 500$ gallon, single lined carbon steel caustic tank. Tank was used to mix sodium

3004D - $\quad 500$ gallon, single lined stainless steel nitric acid tank. Tank provided nitric acid to the water treatment process.

3004F - 1,500 gallon single lined stainless steel nitric acid tank. Tank was used to mix nitric acid during the water treatment process.

$3004 \mathrm{H}$ - 60 gallon, single lined stainless steel nitric acid tank. Tank provided nitric acid to the water treatment process.

- The interior of the building is in poor to fair condition. Empty tanks, remaining asbestos containing material (ACM), and radiation (RAD) hazard areas are posted and/or labeled as appropriate. Painted surfaces throughout the facility are in poor to fair condition.

- According to facility personnel, the roof in this building is in poor condition and leaks.

- Portions of the interior of the building are soiled with bird excrement.

\section{Release Information}

Description of release, or threatened release, and source:

Low levels of residual fixed and transferable radiologic surface contamination reportedly exist in areas of the building as a result of historical activities unrelated to water demineralization. The contamination is associated primarily with equipment and surfaces throughout the facility. This contamination has accumulated from activities involving a variety of materials throughout the operating history of the facility and, therefore, cannot be attributed to a single release episode. The existing levels of RAD contamination in the facility are reportedly low and the presence of this contamination is does not present an immediate hazard given the current status and level of activity of this building.

Hazardous materials (HAZMATs) (e.g., acids, caustics, and other chemicals) were historically used in large quantities (i.e., greater than 5 gallons or 100 pounds) during facility operations. However, current activities in Building 3004 involve only small quantities of HAZMATs (i.e., less than 5 gallons or 100 pounds). According to available spill/release records and facility personnel interviews, no significant HAZMAT spills (i.e., spills having the potential to adversely affect human health and/or the environment) have been reported for this building. No current conditions were identified which present a potential for a significant HAZMAT release.

\section{Hazardous substances present:}

Hazardous substances remaining in Building 3004 consist mainly of residual RAD surface contamination. Areas of fixed and transferable RAD contamination are reportedly associated primarily with equipment and surfaces (walls, floors, etc.).

Small quantities of miscellaneous HAZMATs used for water purification and maintenance activities are also present in the facility. All acid and caustic tanks previously used in the purification process have been taken out of service, drained, and posted with signs indicating that the tank is empty and inactive. 
Estimate (if possible) of quantities of hazardous substances that have been released and that could be released:

No information regarding quantities of hazardous substances existing in Building 3004 was identified during this RmSE. Based on the residual nature of the contamination reportedly present, it is expected that the quantities are small.

Other pollutants or contaminants:

Asbestos containing material, primarily in the form of thermal system insulation, has been confirmed present in this building. Approximately 18 bags of RAD contaminated ACM which has been removed from within the building are currently stored in the building awaiting disposal. Remaining ACM is reportedly in good condition and poses no immediate health threat. Based on the age of the facility, interior and exterior painted surfaces are assumed to be lead-containing. Verification samples are taken by ORNL Lead Management Program personnel on an "as-needed" basis to confirm the presence of lead in the paint (i.e., when work activities will disturb the paint, or paint is found to be deteriorating and poses a health or environmental threat). Interior painted surfaces observed in photographs appear to be in fair condition throughout the facility and pose no immediate health threat given the status of the facility. Paint on exterior surfaces is severely deteriorated. This deterioration is evenly distributed over the entire exterior surface area of the facility.

\section{Groundwater}

Are there any suspected impacts to groundwater? If yes, please describe. Include any impacts to drinking water sources.

Building 3004 is located in Waste Area Grouping 1 at ORNL. Although no specific adverse spills or releases of hazardous substances were identified during this RmSE, it is suspected, based on available environmental studies conducted in WAG 1, that process waste drains and associated piping may have leaked over the life of the facility. [Reportedly, Building 3004 does not have low-level liquid waste (LLLW) service.] Buried process and LLLW piping and some drains have been found to be deteriorated and leaking in other facilities and areas of WAG 1 . Studies have determined that groundwater in WAG 1 has been both radiologically and chemically contaminated. Because of the age and nature of operations in this facility, it is possible that liquid waste from activities involving chemicals and radioisotopes in Building 3004 have historically contributed to WAG 1 groundwater contamination. However, the radionuclides and chemicals detected in the groundwater were common to the processes and activities in many other buildings in the area which makes it difficult to determine exactly which building(s) is, or was, the source of contamination.

Other than the potential for historical impact to groundwater in WAG 1 via leaking process waste lines external to the building, no existing immediate threat to groundwater was identified given the current status of the facility. 


\section{Surface Water}

Are there any suspected impacts to surface water? If yes, please describe. Also describe the most likely surface water migration route(s), if applicable. Include any impacts to drinking water sources.

WAG 1 is essentially bound by Fifth Creek to the east, White Oak Creek (WOC) to the south, and First Creek to the west. First and Fifth creeks flow south into WOC which flows to the west and exits WAG 1 at the southwest comer. Storm water (from surface runoff and storm water drainage system) and treated water from the process waste system discharges into WOC. The only potential for direct impact to surface water from Building 3004 in its current state would be from lead-containing paint chips which fall off the exterior painted surfaces and find their way into the storm water drainage system and eventually to WOC. Exterior paint was found to be severely deteriorated over the entire exterior surface area of the facility. Paint is bubbling, peeling, and flaking away from the surface.

Storm drains are located adjacent to the east and west sides of the building, directly below areas of deteriorating paint. As a result, there is a strong potential for paint chips to be dislodged by rain or wind during a storm event and subsequently be carried into the storm water drainage system with rainwater.

Surface water may have also been indirectly impacted by leaking process waste lines external to the building. Some of these lines are known to have shared a common trench with storm water drainage piping. Contamination from leaking waste lines could potentially enter deteriorated storm water piping and migrate to WOC. The three creeks bordering WAG 1 are groundwater discharge points. Therefore, groundwater contaminated by leaking waste lines could also potentially impact surface water in the area.

Other than the potential for historical impact, the only existing immediate threat to surface water identified during this RmSE is that from the assumed lead-containing exterior paint on the building.

\section{Air}

Are there any suspected impacts due to air emissions? If yes, please describe.

Because of the presence of residual contamination within the facility, a potential exists for radiation exposure to personnel working inside and within the immediate vicinity of the facility due to potential airborne migration of radioactive particulates and physical contact with contaminated surfaces. Areas of RAD contamination are identified, marked, and controlled as appropriate throughout the facility to protect against inadvertent exposure to personnel. Building 3004 does not have a ventilation system. Ventilation is provided by natural draft. Therefore, the building remains at atmospheric pressure. Since there is no mechanical means of controlling air quality within this building (i.e., ventilation system with filtration) a potential exists for airborne contamination to migrate from the building via natural draft. No information was identified during this RmSE to indicate that the presence of RAD contamination within this building has impacted indoor or outdoor air quality in its current state.

A potential also exists for impact to indoor air quality due to the presence of $\mathrm{ACM}$ and assumed lead-based paint (LBP) should these materials be disturbed. The ACM and assumed LBP remaining in the building are not considered to be immediate threats to indoor quality in their current state. 


\section{Soil}

Are there any suspected impacts to soil? If yes, please describe.

The only existing immediate threat to soils identified in the area of Building 3004 is located adjacent to the west side of the facility. Paint on the exterior surfaces of the facility is badly deteriorated and peeling off the building in some areas. This paint is assumed to contain lead by the ORNL Lead Management Office. The soil in the immediate area of Building 3004 is at risk of being impacted by lead contamination from paint that has peeled or chipped off the walls if, in fact, the paint does contain lead.

As stated for groundwater, there is a potential for historical impact to soils in the area of Building 3004 due to leaking process waste drains and piping. Previous environmental studies have identified areas of soil contamination throughout WAG 1 and soil samples collected have detected radioisotopes and chemicals common to the processes performed in this building and surrounding BSF support buildings. Since, these chemicals and radioisotopes were common to the processes in many of the other buildings in the area, it is difficult to determine whether waste from Building 3004 operations has actually contributed to WAG 1 soil contamination based on the information reviewed during this RmSE.

Release Beyond Facility or Reservation Boundaries

Has or will the release migrate beyond the boundaries of the facility or reservation? If yes, please describe (including possible human or environmental receptors).

The following are considered potential scenarios where radiologic contamination could migrate beyond the facility or reservation boundaries:

- A person becomes inadvertently contaminated from residual surface contamination and leaves the facility/reservation undetected.

- An area of residual surface contamination is disturbed, releasing contaminated particulates into the air.

- Catastrophic failure of the building or contaminated equipment.

There is also a potential for assumed lead-containing paint which peels off of the building to be carried away with surface runoff during a rain event. With the exception of exterior paint, these potentials are considered slight and unlikely due to the current status of the facility and the engineering/administrative controls that are in place to protect again such an event.

\section{Worker Safety}

Could the release pose a threat to workers? If yes, please describe.

Radiologically contaminated areas are isolated and well marked. Good radiation practices and standard operating procedures are enforced for worker safety. Access to the building is controlled. Booties and lab coats are required to be worm by personnel entering the building. Personnel exiting the building are required to "frisk" themselves to detect the presence of RAD contamination. Asbestos containing material remaining in the building is appropriately labeled. However, even with these safeguards in place, a potential threat to workers exists if safety measures are overlooked. This potential is not considered significant given the current status and level of activity of the building. 


\begin{tabular}{|l|}
\hline \multicolumn{1}{|c|}{ Environmental Receptors } \\
\hline $\begin{array}{l}\text { Does the release pose a potential threat to environmental receptors? If yes, please describe. Include } \\
\text { natural resources impacts. } \\
\text { No existing conditions posing an immediate significant threat to environmental receptors, including natural } \\
\text { resources, were identified to be currently associated with Building } 3004 .\end{array}$ \\
\hline Mitigation \\
\hline
\end{tabular}

What action(s) might be taken to abate/prevent release or impacts from release?

- Continued utilization and enforcement of engineering and administrative controls that are currently in place to protect workers and monitor conditions and activities in the building.

- Exterior paint on the facility should be tested for lead content. If the paint is found to be leadcontaining, a removal action will be required to eliminate areas of deteriorating paint. In addition, a remedial site evaluation may be necessary to determine whether the soil adjacent to the west side of the building has been impacted by lead from the peeling paint.

- Continue S\&M activities per BSF Surveillance and Maintenance Work Plan, ORNL/RRD/TNT-86/R1.

What actions are currently being taken to abate/prevent release or impacts from release?

Engineering and administrative controls are in place to control access to the building and contaminated areas, and to monitor conditions and activities within the facility for worker and environmental protection. Warning signs and labels are posted throughout the facility indicating RAD and ACM hazard areas. Standard operating procedures are in place for building access, operations, and maintenance activities to protect against inadvertent contact and disturbance of contaminated areas and materials. Radiologically contaminated areas are monitored periodically by ORNL health physics personnel. Personnel are "frisked" upon exiting the facility to detect the presence of radiologic contamination. The building is partially deactivated, but continues to provide demineralized water to facilities while awaiting entry into the Decontamination and Decommissioning (D\&D) Program. The fire protection, electrical, and steam heating systems remain operational to maintain current conditions in the facility. The building is inspected periodically for structural changes and degradation which include any cracking, failure, or deterioration of the facility and/or equipment that may allow contamination to be released.

With the exception of the areas of deteriorating exterior paint, current actions being taken to prevent further release and ensure worker safety in Building 3004 are considered adequate until D\&D activities begin.

\begin{tabular}{|c|}
\hline Other Environmental Authorities \\
\hline $\begin{array}{l}\text { Is the release or threatened release potentially subject to other environmental statutory actions? If yes, } \\
\text { please explain. }\end{array}$ \\
\hline
\end{tabular}


Maintenance Actions

Are maintenance actions necessary to eliminate potential threats to human health and the environment? If so, explain.

Samples should be taken of the exterior paint on the facility. The samples should then be analyzed to determine whether the paint does, in fact, contain lead. Such analysis should include TCLP (40 CFR 261, Appendix II) to determine whether Building 3004 qualifies as a RCRA generator point. If the paint is found to contain lead, abatement actions will be required to prevent deteriorated areas of paint from dislodging and potentially impacting the soil below, and subsequently entering the storm water drainage system which would present a threat to WAG 1 surface water.

No further imminent hazards requiring maintenance actions were identified to be associated with Building 3004.

Removal Actions
Are Removal Actions necessary to eliminate immediate threats to human health and the environment? If
so, explain.
so, explain.

No existing imminent hazards requiring removal actions per 40 CFR 300.415 were identified to be currently associated with Building 3004.

\section{Remedial Site Evaluation}

Is a Remedial Site Evaluation needed?

Pending confirmatory sampling and analysis results of the exterior paint on the facility, a remedial site evaluation (RSE) should be conducted to determine whether the soil adjacent to the west side of the facility has been impacted by lead from chipping paint and whether remediation of the soil is necessary.

Areas of radiologic contamination associated with Building 3004 have been identified and marked as appropriate. However, it is suspected that process waste drains and associated piping may have leaked beneath the slab of the building foundation as a result of past practices. As a result, it is recommended that some type of remedial investigation be performed to assess the condition of the soil in this area before conducting any S\&M or D\&D activities which involve disturbing the slab.

Asbestos containing materials remaining in the building have also been identified, marked and documented. No further remedial investigation involving these hazards is considered necessary given the current status and future plans of this facility.

Based on the age of the facility, painted surfaces are assumed to contain lead. Samples of the paint should be taken and analyzed to verify the presence of lead prior to conducting any S\&M or D\&D activities which may disturb these assumed areas. 


\section{No Further Investigation}

Is a finding of No Further Investigation appropriate? Please explain.

A finding of No Further Investigation implies that a facility or area is free from hazardous substances or contaminants that may threaten human health and the environment. Since Building 3004 contains substances and materials which may become threatening if not properly controlled, handled and managed during the S\&M cycle, a finding of No Further Investigation is inappropriate in this case.

\section{Additional Comments}

The following documents and databases were referenced for historical and hazard information related to Building 3004:

- Work Plan for the High Ranking Facilities Deactivation Project at Oak Ridge National Laboratory, Document No. ORNL/ER-322.

- Bulk Shielding Facility (BSF) Surveillance and Maintenance Work Plan, Document No. ORNL/RRD/INT-86/R1.

- Bulk Shielding Facility Shutdown Plan, Document No. ORNL/RRD/INT-84.

- Site Characterization Summary Report for Waste Area Grouping 1 at Oak Ridge National Laboratory, Oak Ridge, Tennessee, Volumes 1 and 2, Document Nos. DOE/OR-1043/V1\&D1 and DOE/OR1043/V2\&D1.

- ORNL Hazardous Material Information System Database.

- ORNL PCB Inventory Database.

- EM60 Surplus Facility Inventory and Assessment Database.

The following personnel and offices were contacted and provided historical and current use/condition information for Building 3004:

- Mr. R. D. Childs, Facility Manager, Bulk Shielding Facility.

- Mr. Brad Watson, High Ranking Facilities Deactivation Project.

- Ms. Swati Wilson, Manager, ORNL Lead Management Program.

- Mr. Nathan Dunn, Hazardous Material Information System Office.

- Mr. Jade Thomas, ORNL Environmental Compliance Office.

The RmSE of this facility was conducted for LMES under contract by:

Advanced Sciences, Inc.

800 Oak Ridge Turnpike, Suite C-102

Oak Ridge, TN

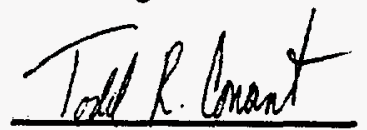

Evaluator's Signature 
4. BUILDING 3009 INFORMATION FORM 

ORNL FACILITY RmSE INFORMATION FORM

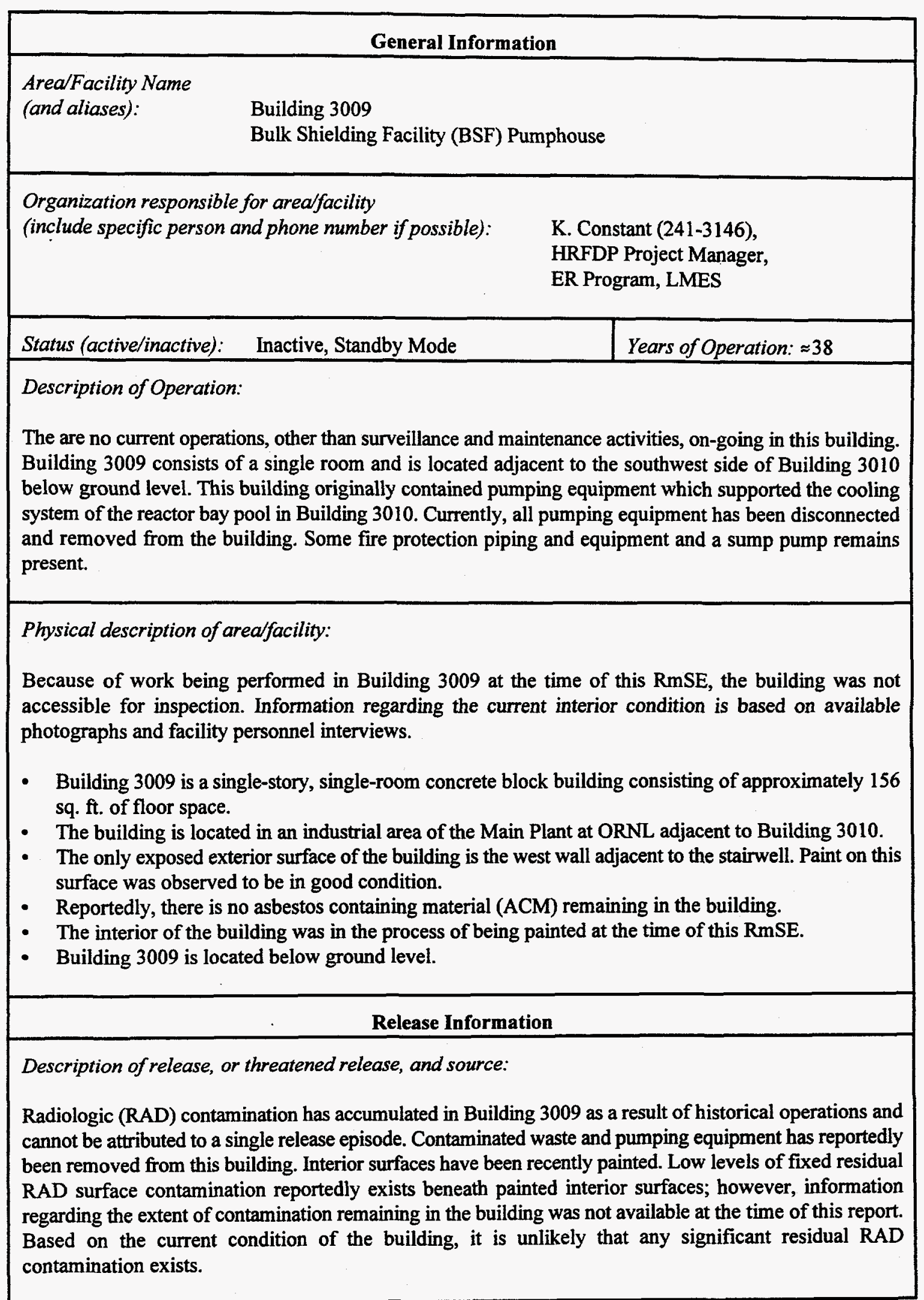


Hazardous substances present:

With the exception of potential low levels of residual RAD surface contamination, all hazardous substances have reportedly been removed from this building.

Estimate (if possible) of quantities of hazardous substances that have been released and that could be released:

No information regarding estimated quantities of existing residual RAD surface contamination in Building 3009 was available at the time of the report.

Other pollutants or contaminants:

Reportedly, no ACM currently exists in this building. Based on the age of the facility, previously painted surfaces are assumed to be lead-containing. Verification samples are taken by ORNL Lead Management Program personnel on an "as-needed" basis to confirm the presence of lead in the paint (i.e., when work activities will disturb the paint, or paint is found to be deteriorating and poses a health or environmental threat). Interior surfaces have recently been painted; therefore, it is unlikely that the new paint contains lead. However, the potential remains if layers of old paint were left on surfaces and painted over. Paint on exterior surfaces of this building is in good condition and does not present an immediate environmental threat.

\section{Groundwater}

Are there any suspected impacts to groundwater? If yes, please describe. Include any impacts to drinking water sources.

Building 3009 is located in Waste Area Grouping 1 at ORNL. Although no specific adverse spills or releases of hazardous substances were identified during this RmSE, it is suspected, based on available environmental studies conducted in WAG 1, that process and Low-Level Liquid Waste (LLLW) drains and associated piping may have leaked over the life of this building or surrounding facilities. Buried process and LLLW piping and some drains have been found to be deteriorated and leaking in other facilities and areas of WAG 1 . Studies have determined that groundwater in WAG 1 has been both radiologically and chemically contaminated. Numerous man-made radionuclides have been detected in WAG 1 groundwater samples including many of those processed/utilized at the Bulk Shielding Facility (BSF). Because of the age and nature of operations in this facility, it is possible that liquid waste from activities involving chemicals and radioisotopes in the BSF have historically contributed to WAG 1 groundwater contamination. However, the radionuclides and chemicals detected in the groundwater were common to the processes and activities in many other buildings in the area which makes it difficult to determine exactly which building is, or was, the source of contamination.

Other than the potential for historical impact to groundwater in WAG 1 via leaking process and LLLW lines external to the building, no existing immediate threat to groundwater was identified given the current status of the facility. 


\section{Surface Water}

Are there any suspected impacts to surface water? If yes, please describe. Also describe the most likely surface water migration route(s), if applicable. Include any impacts to drinking water sources.

WAG 1 is essentially bound by Fifth Creek to the east, White Oak Creek (WOC) to the south, and First Creek to the west. First and Fifth creeks flow south into WOC which flows to the west and exits WAG 1 at the southwest corner. Stormwater (from surface runoff and stormwater drainage system) and treated water from the process waste system discharges into WOC. The only potential for direct impact to surface water from Building 3009 in its current state would be from lead-containing paint chips which fall off the exterior painted surfaces and find their way into the stormwater drainage system and eventually to WOC. The only exposed exterior surface of Building 3009 is the west wall. Paint on this wall was found to be in good condition with no visual evidence of deterioration.

Surface water may have also been indirectly impacted by leaking process and LLLW lines external to the building. Some of these lines are known to have shared a common trench with stormwater drainage piping. Contamination from leaking waste lines could potentially enter deteriorated stormwater piping and migrate to WOC. The three creeks bordering WAG 1 are groundwater discharge points. Therefore, groundwater contaminated by leaking waste lines could also potentially impact surface water in the area.

Other than the potential for historical impact, no existing immediate threat to surface water was identified during this RmSE.

\section{Air}

Are there any suspected impacts due to air emissions? If yes, please describe.

No significant immediate threat to air quality was identified to be associated with Building 3009 given its current status and condition.

Soil

Are there any suspected impacts to soil? If yes, please describe.

As stated for groundwater, there is a potential for historical impact to soils in the area of Building 3009 due to leaking process and LLLW drain piping. Previous environmental studies have identified areas of soil contamination throughout WAG 1 and soil samples collected have detected radioisotopes and chemicals common to the processes performed at the BSF. Since, these radioisotopes were common to the processes in many of the other buildings in the area, it is difficult to determine whether waste from Building 3009 has actually contributed to WAG 1 soil contamination based on the information reviewed during this RmSE.

No other potentials for adverse impact to soils were identified to be currently associated with Building 3009 . 


\section{Release Beyond Facility or Reservation Boundaries}

Has or will the release migrate beyond the boundaries of the facility or reservation? If yes, please describe (including possible human or environmental receptors).

As a result of the presence of residual RAD surface contamination in this facility, the following are considered potential scenarios where radiologic contamination could migrate beyond the facility or reservation boundaries:

- A person becomes inadvertently contaminated from residual surface contamination and leaves the facility/reservation undetected.

- Catastrophic failure of the building.

There is also a potential for paint chips which dislodge from exterior surfaces to be carried away from the facility with stormwater. Though these potentials exist, they are considered slight and unlikely due to the current stans of the facility and the administrative controls that are in place to protect again such an event.

\section{Worker Safety}

Could the release pose a threat to workers? If yes, please describe.

No existing conditions posing an immediate significant threat to workers were identified to be currently associated with Building 3009.

\section{Environmental Receptors}

Does the release pose a potential threat to environmental receptors? If yes, please describe. Include natural resources impacts.

No existing conditions posing an immediate significant threat to environmental receptors, including natural resources, were identified to be currently associated with Building 3009 .

\section{Mitigation}

What action(s) might be taken to abate/prevent release or impacts from release?

- Continued utilization and enforcement of administrative controls that are currently in place to protect workers and monitor conditions and activities in the building.

- Continue S\&M activities per BSF Surveillance and Maintenance Work Plan, ORNL/RRD/INT-86/R1. 
What actions are currently being taken to abate/prevent release or impacts from release?

Radiologically contaminated pumping equipment and waste have reportedly been removed from the building. The interior of the building has been recently cleaned and painted. Access to the building is currently controlled. Personnel exiting the building are currently required to "frisk" their hands and feet; however, according to facility personnel, this requirement will be discontinued upon completion of the cleaning and painting work on-going within the building. Radiologically contaminated areas are monitored periodically by ORNL health physics personnel. The building has been deactivated, and is awaiting entry into the Decontamination and Decommissioning (D\&D) Program. Surveillance and maintenance activities are performed to maintain the condition of the facility until D\&D.

Current actions being taken to maintain facility conditions and ensure worker safety in Building 3009 are considered adequate until D\&D activities begin.

\section{Other Environmental Authorities}

Is the release or threatened release potentially subject to other environmental statutory actions? If yes, please explain.

If paint associated with the facility is found to be lead-containing and samples fail the Toxicity Characteristic Leaching Procedure (TCLP) analysis, the building could qualify as a hazardous waste generator point under the Resource Conservation and Recovery Act (RCRA).

\section{Maintenance Actions}

Are maintenance actions necessary to eliminate potential threats to human health and the environment? If so, explain.

No potential hazards requiring maintenance actions were identified to be associated with Building 3009 .

\section{Removal Actions}

Are Removal Actions necessary to eliminate immediate threat to human health and the environment? If so, explain.

No imminent hazards requiring removal actions per 40 CFR 300.415 were identified to be currently associated with Building 3009.

\section{Remedial Site Evaluation}

\section{Is a Remedial Site Evaluation needed?}

Because of the nature of historical operations at the BSF and documented evidence of subsurface contamination in WAG 1 , it is suspected that process and LLLW drains and associated piping in the BSF area may have leaked beneath the slab and below-grade portion of the Building 3009 foundation. As a result, it is recommended that some type of remedial investigation be performed to assess the condition of the soil in these areas before conducting any S\&M or D\&D activities which involve disturbing the slab.

Based on the age of the facility, exterior painted surfaces are assumed to contain lead. Samples of the paint should be taken and analyzed to verify the presence of lead prior to conducting any S\&M or D\&D activities which may disturb these assumed areas. 
No Further Investigation

Is a finding of No Further Investigation appropriate? Please explain.

A finding of No Further Investigation implies that a facility or area is free from hazardous substances or contaminants that may threaten human health and the environment. Since the building contains residual surface contamination which may become threatening if not properly controlled, handled and managed during the S\&M cycle, and the potential exists for subsurface contamination in the area, a finding of No Further Investigation is inappropriate for Building 3009.

\section{Additional Comments}

The following documents and databases were referenced for historical and hazard information related to Building 3009:

- Work Plan for the High Ranking Facilities Deactivation Project at Oak Ridge National Laboratory, Document No. ORNL/ER-322.

- Bulk Shielding Facility (BSF) Surveillance and Maintenance Work Plan, Document No. ORNL/RRD/INT-86/R1.

- Bulk Shielding Facility Shutdown Plan, Document No. ORNL/RRD/INT-84.

- Site Characterization Summary Report for Waste Area Grouping 1 at Oak Ridge National Laboratory, Oak Ridge Tennessee, Volumes 1 and 2, Document Nos. DOE/OR-1043/V1\&D1 and DOE/OR1043/N2\&D1

- ORNL Hazardous Material Information System Database.

- ORNL PCB Inventory Database.

- EM60 Surplus Facility Inventory and Assessment Database.

The following personnel and offices were contacted and provided historical and current use/condition information for Building 3009:

- Mr. R. D. Childs, Facility Manager, Bulk Shielding Facility.

- Ms. Swati Wilson, Manager, ORNL Lead Management Program.

- Mr. Nathan Dunn, Hazardous Material Information System Office.

- Mr. Jade Thomas, ORNL Environmental Compliance Office.

The RmSE of this facility was conducted for LMES under contract by:

Advanced Sciences, Inc.

800 Oak Ridge Turnpike, Suite C-102

Oak Ridge, TN

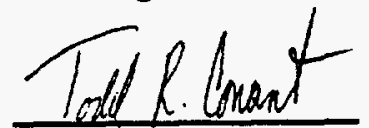

Evaluator's Signature 
5. BUILDING 3010 INFORMATION FORM 
ORNL FACILITY RmSE INFORMATION FORM

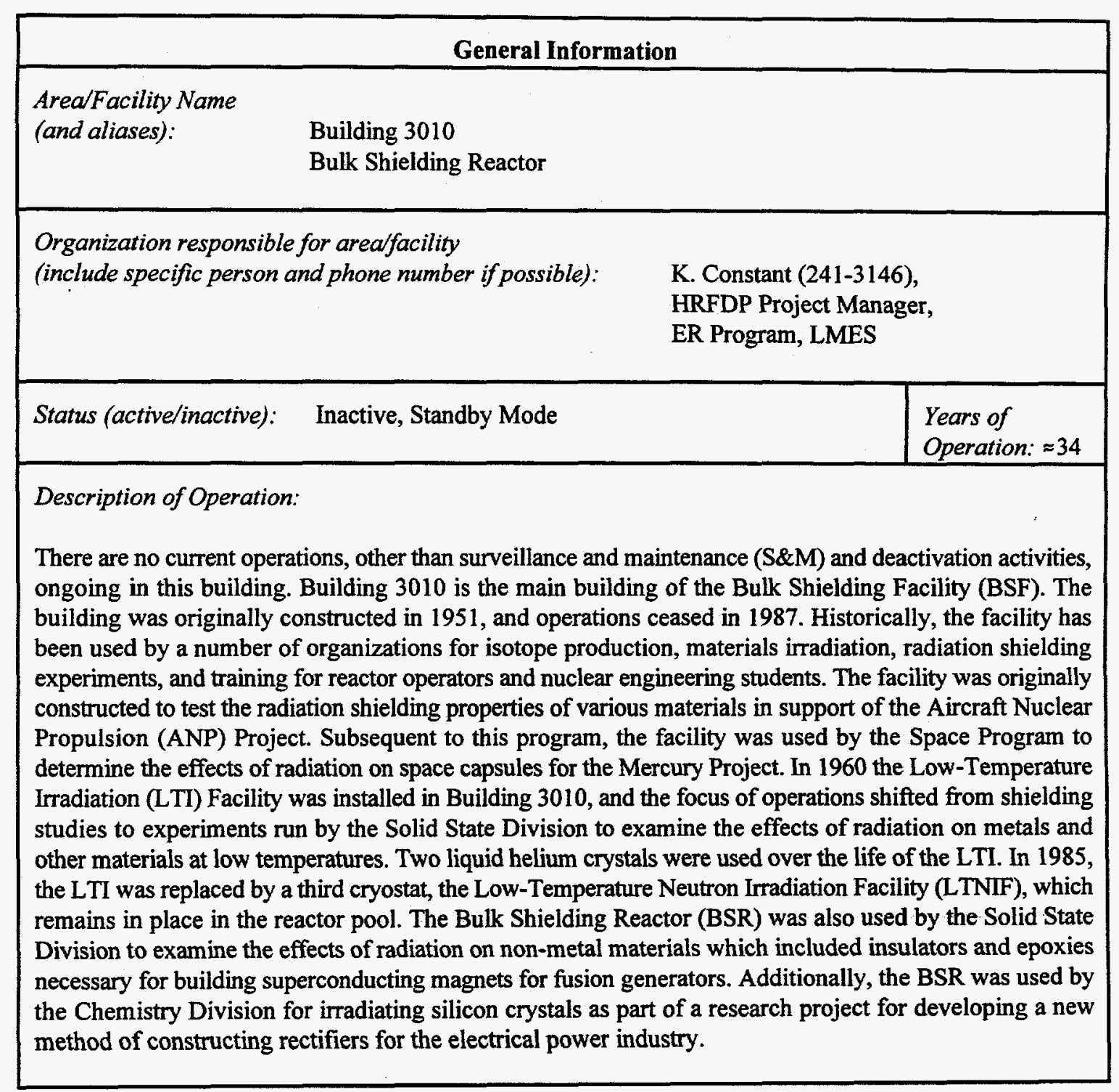


Physical description of arealfacility:

- Building 3010 is a two-story, steel framed building with metal siding consisting of approximately 8,700 sq. $\mathrm{ft}$. of floor space.

- The building is located in an industrial area of the Main Plant at ORNL.

- Paint on exterior surfaces of the building is in good condition.

- Building support systems which remain operational include; steam, ventilation, fire protection, electrical service, safety systems and alarms.

- The immediate area surrounding Building 3010 is mostly paved with some grassy areas to the south.

- Building 3010 contains a 130,000 gallon reactor pool which contains the BSR, the Pool Critical Assembly (PCA), and the LTNIF. The building also contains offices, instrument rooms, equipment rooms, experiment rooms, and a small shop.

- The interior of the building is in fair to good condition. Asbestos containing material (ACM) and radiation (RAD) hazard areas are posted and/or labeled as appropriate. Painted surfaces throughout the facility are in good condition with some localized areas of deterioration in offices, laboratories, and equipment rooms. The roof leaks rainwater, but represents no immediate threat to building integrity or contribution to contaminant migration.

- The ventilation system keeps the reactor bay under negative pressure relative to the interior of the remainder of the building and atmosphere. The building itself is not sealed.

- The building is occupied by 6 people responsible for conducting S\&M activities.

- Reportedly, low-level liquid waste (LLLW) drains within the building are inactive, while floor and reactor pool drains remain active and discharge to the process waste system.

- A building space diagram is attached to this form.

\section{Release Information}

Description of release, or threatened release, and source:

Low levels of residual fixed radiologic surface contamination exist in areas of the facility as a result of historical operations. The contamination is associated primarily with process equipment (vessels, piping, ventilation ducts, etc.). This contamination has accumulated from activities involving a variety of materials throughout the operating history of the facility and, therefore, cannot be attributed to a single release episode. The existing levels of RAD contamination in the facility are reportedly low and the presence of this contamination is not considered a significant hazard in its current state.

Recently, a small fire involving an overheated light ballast occurred in Room 100 of Building 3010 . The fire spread PCB-contaminated ash throughout the immediate area. The light fixture was subsequently repaired, and the areas of ash were cleaned to regulatory requirements as verified by wipe samples collected throughout the affected area. As a result, this release does not present a current hazard to workers in the facility.

Hazardous materials (HAZMATs) (e.g., acids, hydraulic fluids, and other chemicals) were reportedly used in small quantities (i.e., less than 5 gallons or 100 pounds) during facility operations and currently for surveillance and maintenance (S\&M) activities. According to available spill/release records and facility personnel interviews, no significant HAZMAT spills (i.e., spills having the potential to adversely affect human health and/or the environment) have been reported for this building. No current conditions were identified which present a potential for a significant HAZMAT release. 
Hazardous substances present:

Hazardous substances remaining in Building 3010 consist mainly of residual RAD surface contamination. Areas of fixed RAD contamination are associated primarily with process equipment. Additional radiation sources in the facility include spent fuel, radioactive source material, and heavy water $\left(\mathrm{D}_{2} \mathrm{O}\right)$ contaminated with tritium. The fuel consists of standard MTR-type fuel elements with aluminum cladding. The radioactive sources are stored in two locked aluminum cans in the reactor bay pool. These sources include cobalt-60, radium, and antimony-124. Three aluminum tanks containing heavy water contaminated with tritium are also stored in the reactor bay pool. There are also 10 fission chambers used for calibration stored in a locked storage cabinet within the facility.

No items containing polychlorinated bi-phenols (PCBs) were identified within Building 3010 other than small light ballasts in some fluorescent light fixtures.

Small quantities of miscellaneous HAZMATs used for S\&M activities are also present in the facility.

Estimate (if possible) of quantities of hazardous substances that have been released and that could be released:

The following represents the known quantities of substances currently existing in the facility. Radiologic surface contamination has accumulated from a legacy of many different programs and processes and cannot be attributed to a single release episode. It is only possible to quantify release amounts from contamination which currently exists in the facility and/or has been historically documented from past activities.

Spent Fuel:

- $58.9 \mathrm{~kg}$ of uranium (includes both uranium-235 enrichment of $93 \%$ used in the BSR, and $19 \%$ used in the Oak Ridge Research Reactor) stored in the reactor bay pool.

Radioactive Sources:

- $2,000 \mathrm{Ci}$ cobalt-60 stored in reactor bay pool.

- $10 \mathrm{Ci}$ radium stored in reactor bay pool.

- $1.5 \mathrm{E}-4 \mathrm{Ci}$ antimony-124 stored in reactor bay pool.

- $907 \mathrm{~kg}$ tritium contaminated heavy water contained in tanks in reactor bay pool.

- Estimated quantity of residual contamination in the facility was not available at the time of this report.

Other pollutants or contaminants:

Asbestos containing material, primarily in the form of thermal system insulation, has been confirmed present in this building. ACM observed is in good condition and poses no immediate health threat. Based on the age of the facility, interior and exterior painted surfaces are assumed to be lead-containing. Verification samples are taken by ORNL Lead Management Program personnel on an "as-needed" basis to confirm the presence of lead in the paint (i.e., when work activities will disturb the paint, or paint is found to be deteriorating and poses a health or environmental threat). Interior painted surfaces observed are in good condition throughout the facility and pose no immediate health threat. Paint on exterior surfaces is in good condition. 


\begin{abstract}
Groundwater
Are there any suspected impacts to groundwater? If yes, please describe. Include any impacts to drinking water sources.

Building 3010 is located in Waste Area Grouping 1 at ORNL. Although no specific adverse spills or releases of hazardous substances were identified during this RmSE, it is suspected, based on available environmental studies conducted in WAG 1, that process and LLLW drains and associated piping may have leaked over the life of the facility. Buried process and LLLW piping and some drains have been found to be deteriorated and leaking in other facilities and areas of WAG 1. Studies have determined that groundwater in WAG 1 has been both radiologically and chemically contaminated. Numerous man-made radionuclides have been detected in WAG 1 groundwater samples including many of those processed/utilized in Building 3010. It is likely that liquid waste from activities involving radioisotopes in Building 3010 has historically contributed to WAG 1 groundwater contamination. However, the radionuclides detected in the groundwater were common to the processes and activities in many other buildings in the area which makes it difficult to determine exactly which building is, or was, the source of contamination.
\end{abstract}

Because of the reported small quantities of chemicals historically used in this facility, it is unlikely that such usage has significantly contributed to WAG 1 groundwater contamination.

Other than the potential for historical impact to groundwater in WAG 1 via leaking process and LLLW lines external to the building, no existing immediate threat to groundwater was identified given the current status of the facility.

Surface Water

Are there any suspected impacts to surface water? If yes, please describe. Also describe the most likely surface water migration route(s), if applicable. Include any impacts to drinking water sources.

WAG 1 is essentially bound by Fifth Creek to the east, White Oak Creek (WOC) to the south, and First Creek to the west. First and Fifth creeks flow south into WOC which flows to the west and exits WAG 1 at the southwest corner. Storm water (from surface runoff and storm water drainage system) and treated water from the process waste system discharges into WOC. The only potential for direct impact to surface water from Building 3010 in its current state would be from lead-containing paint chips which fall off the exterior painted surfaces and find their way into the storm water drainage system and eventually to WOC.

Surface water may have also been indirectly impacted by leaking process and LLLW lines external to the building. Some of these lines are known to have shared common trenches with storm water drainage piping. Contamination from leaking waste lines could potentially enter deteriorated storm water piping and migrate to WOC. The three creeks bordering WAG 1 are groundwater discharge points. Therefore, groundwater contaminated by leaking waste lines could also potentially impact surface water in the area.

Other than the potential for historical impact, no existing immediate threats to surface water were identified to be associated with facility. 
Air

Are there any suspected impacts due to air emissions? If yes, please describe.

Because of the presence of residual contamination within the facility, a potential exists for radiation exposure to personnel working inside and within the immediate vicinity of the facility due to potential airborne migration of radioactive particulates and physical contact with contaminated surfaces. Areas of RAD contamination are identified, marked, and controlled as appropriate throughout the facility to protect against inadvertent exposure to personnel. Air in Building 3010 is controlled by the ventilation system which exhausts the air through a high efficiency particulate air (HEPA) filter bank located in Building 3098 before it is discharged to the atmosphere through Stack 3039. The draw of the ventilation system creates a slight negative pressure within the reactor bay of Building 3010; however, the building is not sealed. Apart from catastrophic failure of the structure or ventilation system, it is unlikely that radioactive air emissions from Building 3010 would impact personnel or the environment in its current state.

A potential also exists for impact to indoor air quality due to the presence of $\mathrm{ACM}$ and assumed lead-based paint (LBP) should these materials be disturbed. The ACM and assumed LBP remaining in the building are not considered to be immediate threats to indoor quality in their current state.

\section{Soil}

Are there any suspected impacts to soil? If yes, please describe.

As stated for groundwater, there is a potential for historical impact to soils in the area of Building $\mathbf{3 0 1 0}$ due to leaking process and LLLW drain piping. Previous environmental studies have identified areas of soil contamination throughout WAG 1 and soil samples collected have detected radioisotopes common to the processes performed in this building. Since, these radioisotopes were common to the processes in many of the other buildings in the area, it is difficult to determine whether waste from Building $\mathbf{3 0 1 0}$ has actually contributed to WAG 1 soil contamination based on the information reviewed during this RmSE.

Are there any suspected impacts to soil? If yes, please describe. (Continued)

There is also a potential for areas of soil adjacent to the facility to be impacted from lead if, in fact, exterior paint is found to be lead-containing. Deteriorating paint could dislodge from the surface and fall to the soil below. The exterior paint was observed to be good condition and does not pose an immediate threat in its current state.

It is unlikely that the quantities of chemicals that have been, and are being, used in Building 3010 have, or will, significantly impact(ed) soil in the surrounding area. 


\section{Release Beyond Facility or Reservation Boundaries}

Has or will the release migrate beyond the boundaries of the facility or reservation? If yes, please describe (including possible human or environmental receptors).

The following are considered potential scenarios where radiologic contamination could migrate beyond the facility or reservation boundaries:

- A person becomes inadvertently contaminated from residual surface contamination and leaves the facility/reservation undetected.

- Catastrophic failure of the building or contaminated equipment.

There is also a potential for assumed lead-containing paint to peel off of the building and be carried away with surface runoff during a rain event. Though these potentials exist, they are considered slight and unlikely due to the current status of the facility and the engineering/administrative controls that are in place to protect again such an event.

\section{Worker Safety}

Could the release pose a threat to workers? If yes, please describe.

Radiologically contaminated areas are isolated and well marked. Good radiation practices and standard operating procedures are enforced for worker safety. Access to contaminated areas is controlled. Personnel exiting the reactor bay are required to "frisk" themselves to detect the presence of RAD contamination. Monitors and alarms are in place to detect any radioactive release within the building. Asbestos containing material is appropriately labeled. However, even with these safeguards in place, a potential threat to workers exists if safety measures are overlooked. This potential is not considered significant given the current status and level of activity of the building.

\section{Environmental Receptors}

Does the release pose a potential threat to environmental receptors? If yes, please describe. Include natural resources impacts.

No existing conditions posing an immediate significant threat to environmental receptors, including natural resources, were identified to be currently associated with Building 3010 .

\section{Mitigation}

What action(s) might be taken to abate/prevent release or impacts from release?

- Continued utilization and enforcement of engineering and administrative controls that are currently in place to protect workers and monitor conditions and activities in the building.

- Continue S\&M activities per BSF Surveillance and Maintenance Work Plan, ORNL/RRD/INT-86/R1. 
What actions are currently being taken to abate/prevent release or impacts from release?

Engineering and administrative controls are in place to control access to the facility and contaminated areas, and to monitor conditions and activities within the facility for worker and environmental protection. Warning signs and labels are posted throughout the facility indicating RAD and ACM hazard areas. Standard operating procedures are in place for building access and S\&M activities to protect against inadvertent contact and disturbance of contaminated areas and materials. Radiologically contaminated areas are monitored periodically by ORNL health physics personnel. Radioactive inventory is containerized and stored in the reactor bay pool which is maintained and monitored for shielding purposes.

Personnel are "frisked" upon exit of contaminated areas of the facility (reactor bay) to detect the presence of radiologic contamination. The building is currently deactivated and in S\&M status awaiting entry into the Decontamination and Decommissioning (D\&D) Program. The ventilation, fire protection, electrical, and steam heating systems remain operational to maintain current conditions in the facility and prevent inadvertent contamination discharge. The building is inspected periodically for structural changes and degradation which include any cracking, failure, or deterioration of the facility and/or equipment that may allow contamination to be released.

Current actions being taken to prevent further release and ensure worker safety in Building 3010 are considered adequate until D\&D activities begin.

\section{Other Environmental Authorities}

Is the release or threatened release potentially subject to other environmental statutory actions? If yes, please explain.

If paint associated with the facility is found to be lead-containing and samples fail the Toxicity Characteristic Leaching Procedure (TCLP) analysis, the building could qualify as a hazardous waste generator point under the Resource Conservation and Recovery Act (RCRA).

\section{Maintenance Actions}

Are maintenance actions necessary to eliminate potential threats to human health and the environment? If so, explain.

No potential hazards requiring maintenance actions were identified to be currently associated with Building 3010.

\section{Removal Actions}

Are removal actions necessary to eliminate immediate threat to human health and the environment? If so, explain.

No imminent hazards requiring removal actions per 40 CFR 300.415 were identified to be currently associated with Building 3010. 


\section{Remedial Site Evaluation}

Is a Remedial Site Evaluation needed?

Areas of radiologic contamination associated with Building 3010 have been identified and marked as appropriate. However, it is suspected that process and LLLW drains and associated piping may have leaked beneath the slab and below-grade portions of the building foundation as a result of past practices. As a result, it is recommended that some type of remedial investigation be performed to assess the condition of the soil in this area before conducting any $S \& M$ or D\&D activities which involve disturbing the slab.

Is a Remedial Site Evaluation needed? (Continued)

Asbestos containing materials have also been identified, marked and documented. No further remedial investigation involving these hazards is considered necessary given the current status and future plans of this facility.

Based on the age of the facility, painted surfaces are assumed to contain lead. Samples of the paint should be taken and analyzed to verify the presence of lead prior to conducting any S\&M or D\&D activities which may disturb these assumed areas.

\section{No Further Investigation}

Is a finding of No Further Investigation appropriate? Please explain.

A finding of No Further Investigation implies that a facility or area is free from hazardous substances or contaminants that may threaten human health and the environment. Since Building 3010 contains substances and materials which may become threatening if not properly controlled, handled and managed during the S\&M cycle, a finding of No Further Investigation is inappropriate in this case. 


\section{Additional Comments}

The following documents and databases were referenced for historical and hazard information related to Building 3010:

- Work Plan for the High Ranking Facilities Deactivation Project at Oak Ridge National Laboratory, Document No. ORNL/ER-322.

- Bulk Shielding Facility (BSF) Surveillance and Maintenance Work Plan, Document No. ORNL/RRD/INT-86/R1.

- Bulk Shielding Facility Shutdown Plan, Document No. ORNL/RRD/INT-84.

- Site Characterization Summary Report for Waste Area Grouping 1 at Oak Ridge National Laboratory, Oak Ridge Tennessee, Volumes 1 and 2, Document Nos. DOE/OR-1043/V1\&D1 and DOE/OR1043/V2\&D1

- ORNL Hazardous Material Information System Database.

- ORNL PCB Inventory Database.

- EM60 Surplus Facility Inventory and Assessment Database.

The following personnel and offices were contacted and provided historical and current use/condition information for Building 3010:

- Mr. R. D. Childs, Facility Manager, Bulk Shielding Facility.

- Ms. Swati Wilson, Manager, ORNL Lead Management Program.

- Mr. Nathan Dunn, Hazardous Material Information System Office.

- Mr. Jade Thomas, ORNL Environmental Compliance Office.

The RmSE of this facility was conducted for LMES under contract by:

Advanced Sciences, Inc.

800 Oak Ridge Turnpike, Suite C-102

Oak Ridge, TN

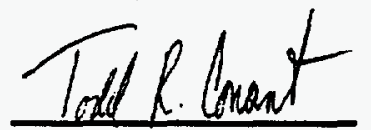

Evaluator's Signature 
5-12

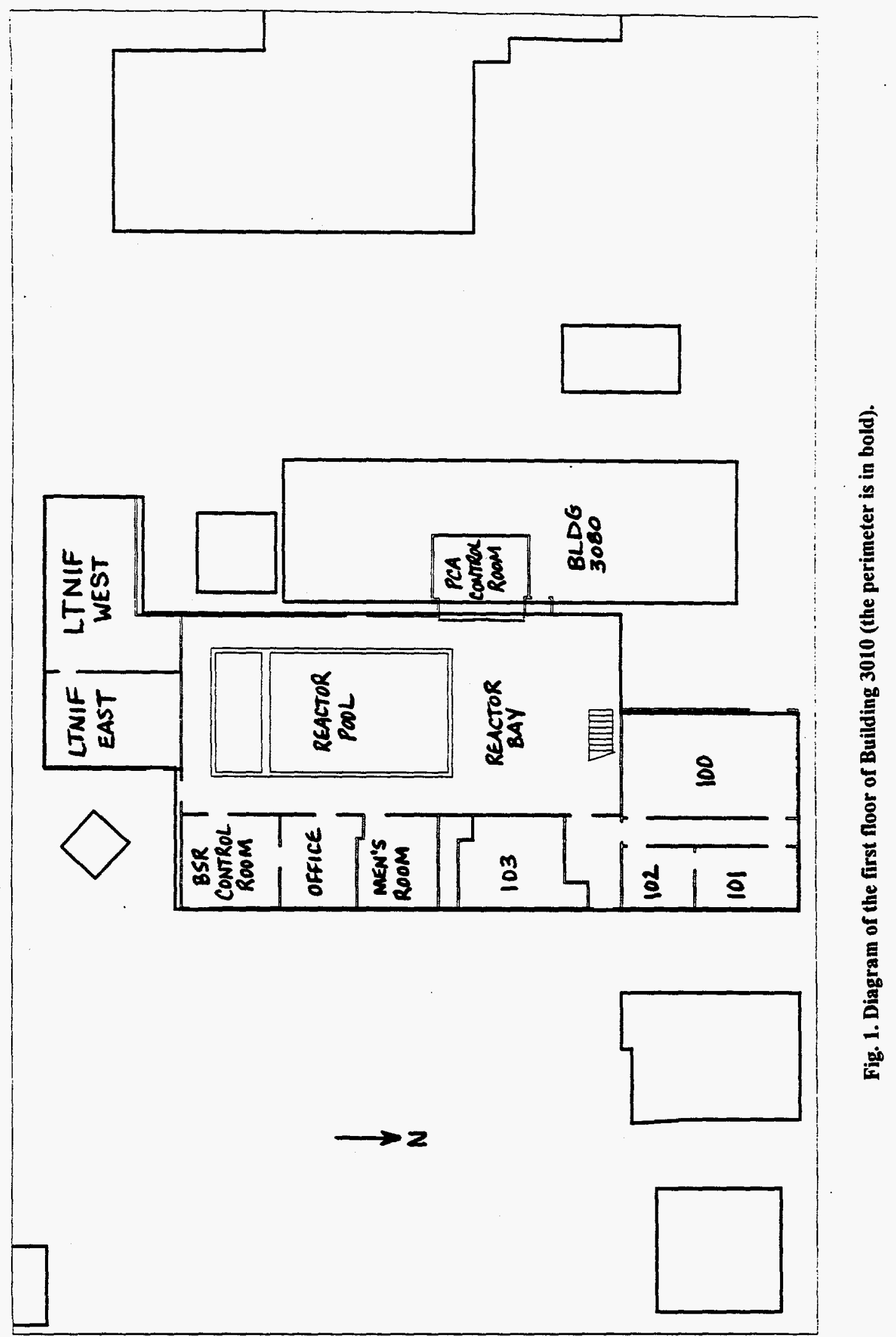


5-13

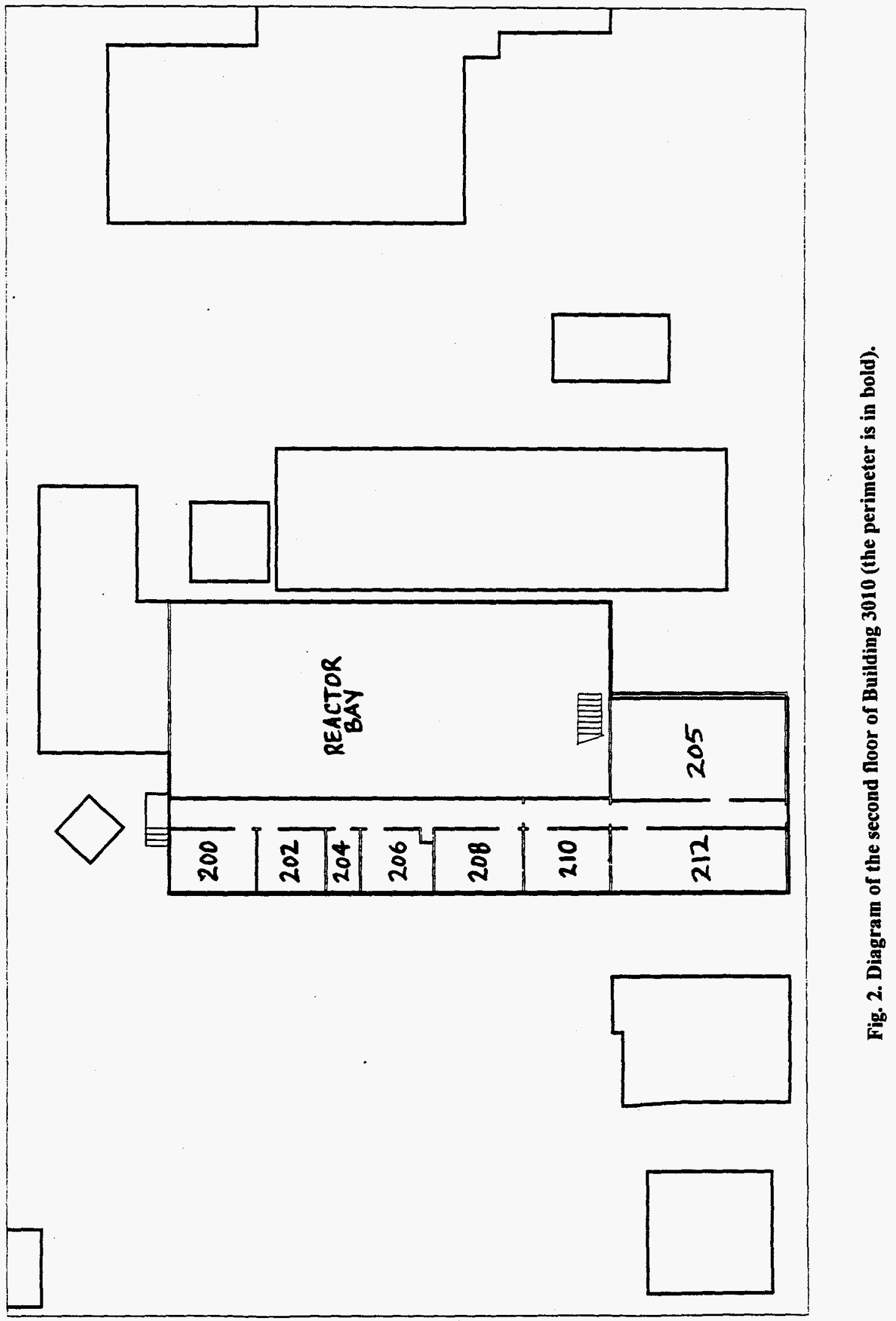


6. BUILDING 3088 INFORMATION FORM 
ORNL FACILITY RmSE INFORMATION FORM

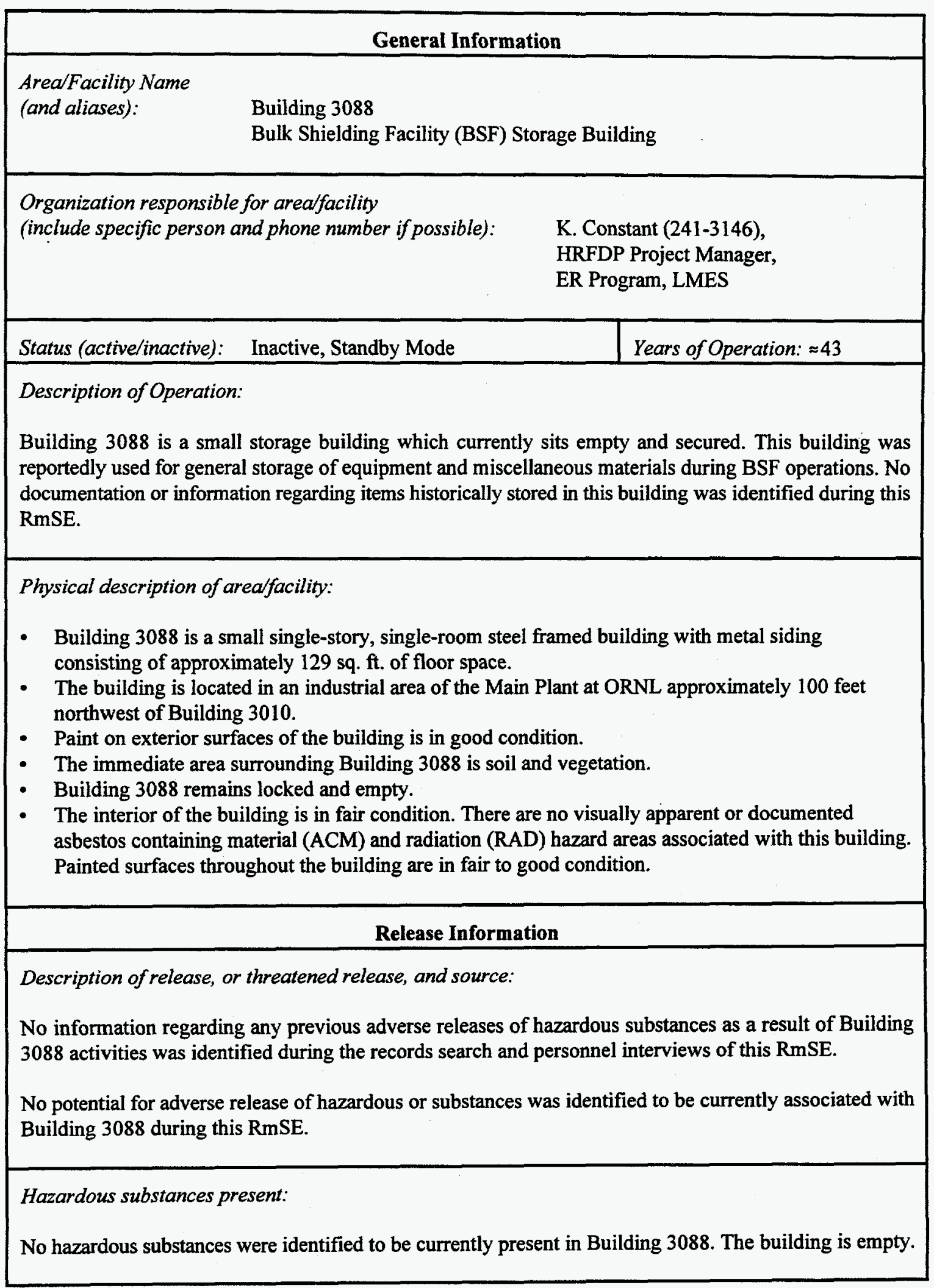


Estimate (if possible) of quantities of hazardous substances that have been released and that could be released:

No information regarding quantities of hazardous substances historically stored in Building $\mathbf{3 0 8 8}$ was identified during this RmSE. Currently there are no quantities of hazardous substances present in the building.

Other pollutants or contaminants:

Based on the age of the facility, interior and exterior painted surfaces are assumed to be lead-containing. Verification samples are taken by ORNL Lead Management Program personnel on an "as-needed" basis to confirm the presence of lead in the paint (i.e., when work activities will disturb the paint, or paint is found to be deteriorating and poses a health or environmental threat). Interior and exterior painted surfaces are in fair to good condition and pose no immediate health threat given the status of the facility.

\section{Groundwater}

Are there any suspected impacts to groundwater? If yes, please describe. Include any impacts to drinking water sources.

No information was identified during this RmSE to suggest that historical activities involving Building 3088 have contributed to Waste Area Grouping (WAG) 1 groundwater contamination. Additionally, no existing immediate threat to groundwater was identified to be currently associated with this building.

\section{Surface Water}

Are there any suspected impacts to surface water? If yes, please describe. Also describe the most likely surface water migration route(s), if applicable. Include any impacts to drinking water sources.

WAG 1 is essentially bound by Fifth Creek to the east, White Oak Creek (WOC) to the south, and First Creek to the west. First and Fifth creeks flow south into WOC which flows to the west and exits WAG 1 at the southwest corner. Storm water (from surface runoff and storm water drainage system) and treated water from the process waste system discharges into WOC. The only apparent potential for historic or current impact to surface water from Building 3088 would be from lead-containing paint chips which fall off the exterior painted surfaces and find their way into the storm water drainage system and eventually to WOC. Since exterior paint was found to be in good condition, this potential is considered to be slight.

No other existing threats to surface water were identified to be currently associated with Building 3088 during this RmSE.

\section{Air}

Are there any suspected impacts due to air emissions? If yes, please describe.

The only existing potential for impact to air quality is due to the presence of assumed lead-based paint (LBP) if the paint is improperly disturbed. Assumed LBP remaining in the building is not considered to be an immediate threat given the current condition and status of the building. 
Soil

Are there any suspected impacts to soil? If yes, please describe.

The only existing potential threat to soils is the presence of assumed LBP on exterior surfaces of the building. Paint chips which fall off these surfaces have the potential to impact the soil below. Assumed LBP remaining on the exterior surfaces is not considered to be an immediate threat given the current condition and status of the building.

\section{Release Beyond Facility or Reservation Boundaries}

Has or will the release migrate beyond the boundaries of the facility or reservation? If yes, please describe (including possible human or environmental receptors).

No historic or current adverse release of hazardous substances was identified to be associated with Building 3088 ; therefore, there is no threat of contaminant migration beyond facility or reservation boundaries.

\section{Worker Safety}

Could the release pose a threat to workers? If yes, please describe.

No conditions posing a significant threat to workers was identified to be currently associated with Building 3088. However, due to the potential for physical hazards, the building remains locked to control access.

\section{Environmental Receptors}

Does the release pose a potential threat to environmental receptors? If yes, please describe. Include natural resources impacts.

No existing conditions posing an immediate significant threat to environmental receptors, including natural resources, were identified to be currently associated with Building 3088.

\section{Mitigation}

What action(s) might be taken to abate/prevent release or impacts from release?

No conditions presenting a potential for adverse release or impact from release were identified to be currently associated with this building. The building is empty and represents no apparent hazard in its current state. Therefore, no mitigation actions are considered to be required to maintain this building in a safe state.

What actions are currently being taken to abate/prevent release or impacts from release?

No conditions representing a significant threat to human health or the environment were identified to be associated with this building; therefore, current actions being taken to ensure worker safety and maintain Building 3088 are considered adequate until D\&D activities begin. 


\begin{tabular}{|c|}
\hline Other Environmental Authorities \\
\hline \multirow{2}{*}{$\begin{array}{l}\text { Is the release or threatened release potentially subject to other environmental statutory actions? If yes, } \\
\text { please explain. } \\
\text { If paint associated with the facility is found to be lead-containing and samples fail the Toxicity } \\
\text { Characteristic Leaching Procedure (TCLP) analysis, the building could qualify as a hazardous waste } \\
\text { generator point under the Resource Conservation and Recovery Act (RCRA). }\end{array}$} \\
\hline \\
\hline Maintenance Actions \\
\hline \multirow{2}{*}{$\begin{array}{l}\text { Are maintenance actions necessary to eliminate potential threats to human health and the environment? } \\
\text { If so, explain. } \\
\text { No potential hazards requiring maintenance actions were identified to be currently associated with Building } \\
3088 \text {. }\end{array}$} \\
\hline \\
\hline Removal Actions \\
\hline \multirow{2}{*}{$\begin{array}{l}\text { Are Removal Actions necessary to eliminate immediate threat to human health and the environment? If } \\
\text { so, explain. } \\
\text { No imminent hazards requiring removal actions per } 40 \text { CFR } 300.415 \text { were identified to be currently } \\
\text { associated with Building } 3088 \text {. }\end{array}$} \\
\hline \\
\hline Remedial Site Evaluation \\
\hline \multirow{2}{*}{$\begin{array}{l}\text { Is a Remedial Site Evaluation needed? } \\
\text { Based on the age of the facility, painted surfaces are assumed to contain lead. Samples of the paint } \\
\text { should be taken and analyzed to verify the presence of lead prior to conducting any S\&M or D\&D } \\
\text { activities which may disturb these assumed areas. }\end{array}$} \\
\hline \\
\hline No Further Investigation \\
\hline Is a finding of No Further Investigation appropriate? Please explain. \\
\hline $\begin{array}{l}\text { A finding of No Further Investigation implies that a facility or area is free from hazardous substances or } \\
\text { contaminants that may threaten human health and the environment. Since Building } 3088 \text { contains } \\
\text { materials which may become threatening if not properly controlled, handled and managed during the } \\
\text { S\&M cycle (potential lead-based paint), a finding of No Further Investigation is inappropriate in this } \\
\text { case. It should be noted, however, that if the paint associated with this building is found not to contain } \\
\text { lead, Building } 3088 \text { would be suitable for a No Further Investigation Determination in accordance with } \\
\text { the guidelines set forth in ES/ER/TM-161, Rev. 0, "Site Evaluation Process for the DOE-ORO } \\
\text { Environmental Restoration Program". }\end{array}$ \\
\hline
\end{tabular}




\section{Additional Comments}

The following documents and databases were referenced for historical and hazard information related to Building 3088:

- Work Plan for the High Ranking Facilities Deactivation Project at Oak Ridge National Laboratory, Document No. ORNL/ER-322.

- Bulk Shielding Facility (BSF) Surveillance and Maintenance Work Plan, Document No. ORNL/RRD/INT-86/R1.

- Bulk Shielding Facility Shutdown Plan, Document No. ORNL/RRD/nNT-84.

- Site Characterization Summary Report for Waste Area Grouping 1 at Oak Ridge National Laboratory, Oak Ridge Tennessee, Volumes 1 and 2, Document Nos. DOE/OR-1043/V1\&D1 and DOE/OR.1043/V2\&D1

- ORNL Hazardous Material Information System Database.

- ORNL PCB Inventory Database.

- EM60 Surplus Facility Inventory and Assessment Database.

The following personnel and offices were contacted and provided historical and current use/condition information for Building 3088:

- Mr. R. D. Childs, Facility Manager, Bulk Shielding Facility.

- Ms. Swati Wilson, Manager, ORNL Lead Management Program.

- Mr. Nathan Dunn, Hazardous Material Information System Office.

- Mr. Jade Thomas, ORNL Environmental Compliance Office.

The RmSE of this facility was conducted for LMES under contract by:

Advanced Sciences, Inc.

800 Oak Ridge Turnpike, Suite C-102

Oak Ridge, TN

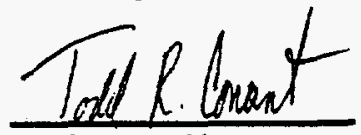

Evaluator's Signature 

7. BUILDING 3098 INFORMATION FORM 

\begin{tabular}{|} 
\\
$\mid$ \\
\\
\end{tabular} 
ORNL FACILITY RmSE INFORMATION FORM

\begin{tabular}{|c|c|}
\hline \multicolumn{2}{|c|}{ General Information } \\
\hline \multicolumn{2}{|c|}{$\begin{array}{ll}\text { Area/Facility Name } & \\
\text { (and aliases): } & \text { Building } 3098 \\
& \text { Bulk Shielding Facility (BSF) Filter House }\end{array}$} \\
\hline \multicolumn{2}{|c|}{$\begin{array}{ll}\text { Organization responsible for arealfacility } & \\
\text { (include specific person and phone number if possible): } & \text { K. Constant (241-3146), } \\
& \text { HRFDP Project Manager, } \\
& \text { ER Program, LMES }\end{array}$} \\
\hline Status (active/inactive): Active & Years of Operation: $\approx 38$ \\
\hline \multicolumn{2}{|c|}{$\begin{array}{l}\text { Description of Operation: } \\
\text { Building } 3098 \text { is a small building housing the high efficiency particulate air (HEPA) filters for the BSF and } \\
\text { Oak Ridge Research Reactor (ORR) ventilation systems. Currently, air from the reactor bay of Building } \\
3010 \text { continues to be exhausted through the filters in Building } 3098 \text { before being discharged to atmosphere } \\
\text { through Stack } 3039 \text {. }\end{array}$} \\
\hline \multicolumn{2}{|c|}{$\begin{array}{l}\text { Physical description of area/facility: } \\
\text { - Building } 3098 \text { is a small single-story, single-room concrete structure. Documentation reviewed } \\
\text { during this RmSE indicates that the building consists of approximately } 1,231 \text { sq. } \mathrm{ft} \text {. of floor space. } \\
\text { However, upon visual inspection, the square footage was found to be much less (approximately } 150 \\
\text { to } 250 \text { sq. ft.). } \\
\text { The building is located in an industrial area of the Main Plant at ORNL approximately } 200 \text { yards } \\
\text { south of Building } 3010 \text {. } \\
\text { - The building is constructed into the side of a hill. The north wall of the building is below grade, the } \\
\text { east and west walls are partially exposed, and the south wall is completely exposed. } \\
\text { - Paint on exposed exterior surfaces of the building is in good condition. } \\
\text { - The immediate area surrounding Building } 3098 \text { is primarily soil and vegetation. } \\
\text { - The building remains locked to control access. } \\
\text { - The interior of the building is in good condition. Interior surfaces are not painted. }\end{array}$} \\
\hline \multicolumn{2}{|c|}{ Release Information } \\
\hline \multicolumn{2}{|c|}{$\begin{array}{l}\text { Description of release, or threatened release, and source: } \\
\text { Documentation reviewed during this RmSE indicated that } 75 \text { percent of this building contains "high } \\
\text { levels" of radiologic (RAD) contamination associated with walls, floors, equipment, piping, and ducts. } \\
\text { However, no RAD contamination postings or warning labels were observed upon visual inspection of } \\
\text { the building. Facility personnel indicated that contamination is only associated with the internal surfaces } \\
\text { of the ventilation duct and HEPA filters. }\end{array}$} \\
\hline
\end{tabular}


Hazardous substances present:

Residual RAD surface contamination reportedly exists on internal surfaces of ducting and associated filters in this building. Although documentation reviewed during this RmSE indicates the presence of residual contamination on interior building surfaces, no supporting evidence of this situation was observed during the building inspection, nor was such identified during facility personnel interviews. If residual RAD contamination does exist within the facility, as available documentation suggests, it is not apparent by visual observation, nor are facility personnel aware of such a situation.

No other hazardous substances were identified to be associated with Building 3098 .

Estimate (if possible) of quantities of hazardous substances that have been released and that could be released:

No information regarding quantities of residual contamination within Building 3098 was identified during this RmSE.

Other pollutants or contaminants:

Based on the age of the facility, interior and exterior painted surfaces are assumed to be lead-containing. Verification samples are taken by ORNL Lead Management Program personnel on an "as-needed" basis to confirm the presence of lead in the paint (i.e., when work activities will disturb the paint, or paint is found to be deteriorating and poses a health or environmental threat). Interior surfaces of this building are not painted, and exterior painted surfaces were observed to be in good condition, posing no immediate threat to human health or the environment.

No other pollutants or contaminants were identified to be associated with this building during this RmSE.

\section{Groundwater}

Are there any suspected impacts to groundwater? If yes, please describe. Include any impacts to drinking water sources.

No evidence was identified during this RmSE to suggest that historical activities associated with Building 3098 have contributed to Waste Area Grouping (WAG) 1 groundwater contamination. Additionally, no existing immediate threat to groundwater was identified to be associated with this building.

\section{Surface Water}

Are there any suspected impacts to surface water? If yes, please describe. Also describe the most likely surface water migration route(s), if applicable. Include any impacts to drinking water sources.

WAG 1 is essentially bound by Fifth Creek to the east, White Oak Creek (WOC) to the south, and First Creek to the west. First and Fifth creeks flow south into WOC which flows to the west and exits WAG 1 at the southwest corner. Storm water (from surface runoff and storm water drainage system) and treated water from the process waste system discharges into WOC. The only apparent potential for historic or current impact to surface water from Building 3098 would be from lead-containing paint chips which fall off the exterior painted surfaces and find their way into the storm water drainage system and eventually to WOC. Since exterior paint was found to be in good condition, this potential is considered to be slight.

No other existing threats to surface water were identified to be associated with Building 3098 during this RmSE. 


\section{Air}

Are there amy suspected impacts due to air emissions? If yes, please describe.

Apart from catastrophic failure of the structure and contaminated ventilation equipment, no significant threats to air quality were identified to be associated with Building 3098 during this RmSE.

\section{Soil}

Are there any suspected impacts to soil? If yes, please describe.

The only existing potential threat to soils is the presence of assumed lead-based paint (LBP) on exterior surfaces of the building. Paint chips which fall off these surfaces have the potential to impact the soil below. Assumed LBP remaining on the exterior surfaces is in good condition and not considered to be an immediate threat.

\section{Release Beyond Facility or Reservation Boundaries}

Has or will the release migrate beyond the boundaries of the facility or reservation? If yes, please describe (including possible human or environmental receptors).

The following are considered potential scenarios where radiologic contamination could migrate beyond the facility or reservation boundaries:

- A person becomes inadvertently contaminated from residual surface contamination and leaves the facility/reservation undetected.

- Catastrophic failure of the building or contaminated equipment.

There is also a potential for assumed lead-containing paint which peels off the building to be carried away from the facility and off-site with surface runoff during a rain event. Though these potentials exist, they are considered slight and unlikely due to the current status and condition of the facility and the administrative controls that are in place to protect again such an event.

\section{Worker Safety}

Could the release pose a threat to workers? If yes, please describe.

Good radiation practices and standard operating procedures governing maintenance activities involving the building are enforced for worker safety. The building remains locked to control unauthorized access. However, even with these safeguards in place, a potential threat to workers exists if safety measures are overlooked. This potential is not considered significant given the current status and level of activity associated with this building.

\section{Environmental Receptors}

Does the release pose a potential threat to environmental receptors? If yes, please describe. Include natural resources impacts.

No existing conditions posing an immediate significant threat to environmental receptors, including natural resources, were identified to be currently associated with Building 3098. 
Mitigation
What action(s) might be taken to abate/prevent release or impacts from release?
- Labeling of RAD contaminated areas/equipment within the building, as appropriate.
- Continued utilization and enforcement of administrative controls that are currently in place to protect workers and monitor conditions and activities in the building.

- Continue S\&M activities per BSF Surveillance and Maintenance Work Plan, ORNL/RRD/INT-86/R1.

What actions are currently being taken to abate/prevent release or impacts from release?

Engineering and administrative controls are in place to control access to contaminated areas within Building 3098 and to monitor conditions and activities for worker and environmental protection. Standard operating procedures are in place for building access and surveillance and maintenance (S\&M) activities to protect against inadvertent contact and disturbance of contaminated areas and materials. The building remains active in support of BSF ventilation needs while awaiting entry into the Decontamination and Decommissioning (D\&D) Program.

Current actions being taken to prevent further release and ensure worker safety in Building 3098 are considered adequate until D\&D activities begin.

\section{Other Environmental Authorities}

Is the release or threatened release potentially subject to other environmental statutory actions? If yes, please explain.

If paint associated with the facility is found to be lead-containing and samples fail the Toxicity Characteristic Leaching Procedure (TCLP) analysis, the building could qualify as a hazardous waste generator point under the Resource Conservation and Recovery Act (RCRA).

Maintenance Actions

Are maintenance actions necessary to eliminate potential threats to human health and the environment? If so, explain.

No potential hazards requiring maintenance actions were identified to be associated with Building 3098 . However, areas of internal RAD contamination are reportedly associated with the ventilation equipment within the building. No RAD contamination warning labels or postings were observed upon visual inspection of the building. Areas of RAD contamination should be marked/identified within the building to assure worker safety. The absence of warning signs and labels is not considered an immediate hazard because of the locked status of the building, the indirect accessibility of contaminated areas, and the existing procedures in place governing $S \& M$ activities associated with the building which include periodic changes of the HEPA filters which could potentially be contaminated. Labeling the contaminated areas in this case is a matter of good safety practice and awareness. Additionally, the EM60 Surplus Facility Inventory and Assessment Database and the HRFDP work plan should be revised to reflect actual conditions in this building. Currently, these sources of information indicate that 75 percent of this building is contaminated with "high levels" of RAD contamination, including wall and floor surfaces. This information is mis-leading and should be corrected. 


\begin{tabular}{|c|}
\hline Removal \\
\hline $\begin{array}{l}\text { Are Removal Actions necessary to eliminate immediate threat to human health and the environment? If } \\
\text { so, explain. } \\
\text { No existing imminent hazards requiring removal actions per } 40 \text { CFR } 300.415 \text { were identified to be currently } \\
\text { associated with Building } 3098 \text {. }\end{array}$ \\
\hline Remedial Site Evaluation \\
\hline \multirow{2}{*}{$\begin{array}{l}\text { Is a Remedial Site Evaluation needed? } \\
\text { Based on the age of the facility, painted surfaces are assumed to contain lead. Samples of the paint should } \\
\text { be taken and analyzed to verify the presence of lead prior to conducting any S\&M or D\&D activities which } \\
\text { may disturb these assumed areas. }\end{array}$} \\
\hline \\
\hline No Further Investigation \\
\hline $\begin{array}{l}\text { Is a finding of No Further Investigation appropriate? Please explain. } \\
\text { A finding of No Further Investigation implies that a facility or area is free from hazardous substances or } \\
\text { contaminants that may threaten human health and the environment. Since Building } 3098 \text { contains } \\
\text { substances and materials which may become threatening if not properly controlled, handled and managed } \\
\text { during the S\&M cycle, a finding of No Further Investigation is inappropriate in this case. }\end{array}$ \\
\hline Additional Comments \\
\hline $\begin{array}{l}\text { The following documents and databases were referenced for historical and hazard information related to } \\
\text { Building 3098: } \\
\text { - Work Plan for the High Ranking Facilities Deactivation Project at Oak Ridge National Laboratory, } \\
\text { Document No. ORNL/ER-322. } \\
\text { - Bulk Shielding Facility (BSF) Surveillance and Maintenance Work Plan, Document No. } \\
\text { ORNL/RRD/INT-86/R1. } \\
\text { - Bulk Shielding Facility Shutdown Plan, Document No. ORNL/RRD/NT-84. } \\
\text { - Site Characterization Summary Report for Waste Area Grouping } 1 \text { at Oak Ridge National Laboratory, } \\
\text { Oak Ridge Tennessee, Volumes } 1 \text { and 2, Document Nos. DOE/OR-1043/V1\&D1 and DOE/OR- } \\
\text { 1043/V2\&D1 } \\
\text { - ORNL Hazardous Material Information System Database. } \\
\text { - ORNL PCB Inventory Database. } \\
\text { - EM60 Surplus Facility Inventory and Assessment Database. } \\
\text { The following personnel and offices were contacted and provided historical and current use/condition } \\
\text { information for Building } 3098 \text { : } \\
\text { - Mr. R. D. Childs, Facility Manager, Bulk Shielding Facility. } \\
\text { - Ms. Swati Wilson, Manager, ORNL Lead Management Program. } \\
\text { - Mr. Nathan Dunn, Hazardous Material Information System Office. } \\
\text { - Mr. Jade Thomas, ORNL Environmental Compliance Office. }\end{array}$ \\
\hline
\end{tabular}

The RmSE of this facility was conducted for LMES under contract by:

Advanced Sciences, Inc.

800 Oak Ridge Turnpike, Suite C-102

Oak Ridge, TN

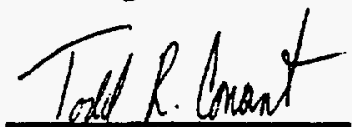

Evaluator's Signature 8/28/96 Date 

8. BUILDING 3101 INFORMATION FORM 

ORNL FACILITY RmSE INFORMATION FORM

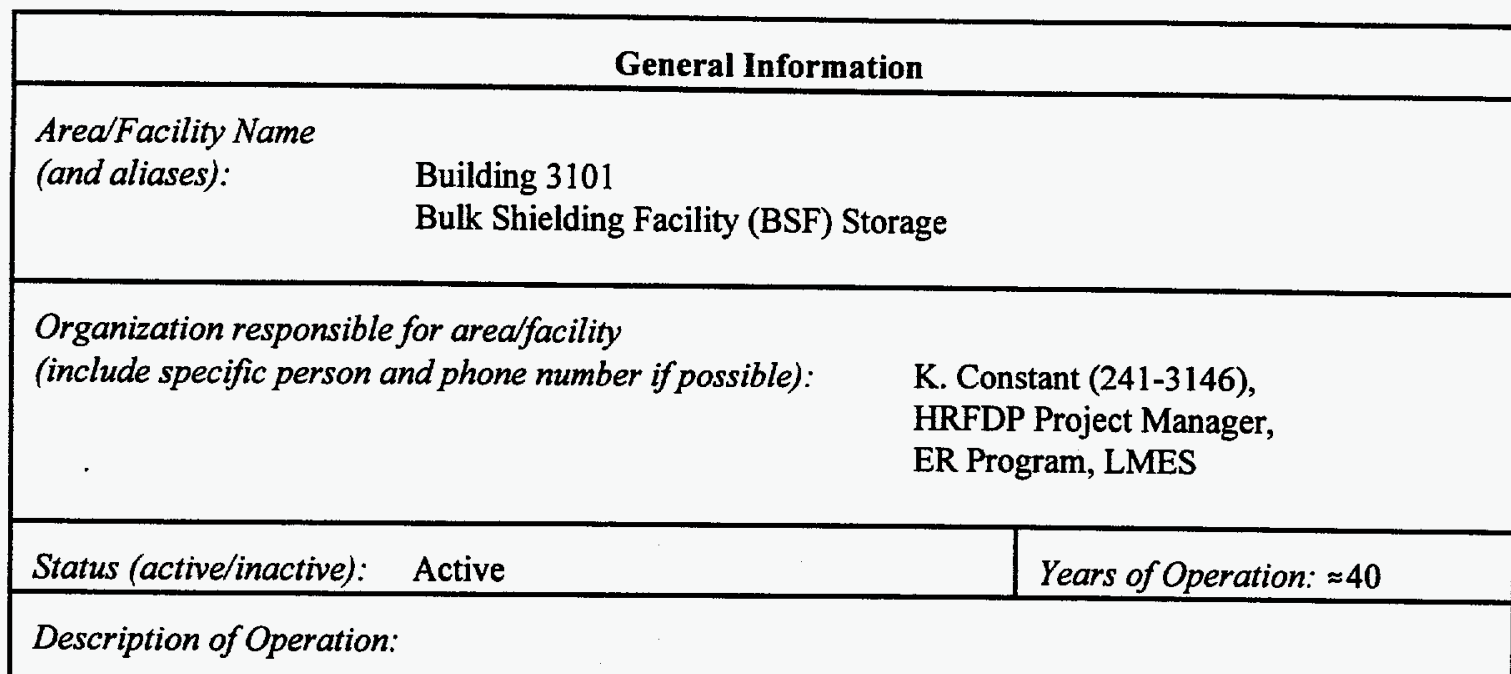

Building 3101 is used for storage of miscellaneous materials and equipment for BSF activities.

Physical description of arealfacility:

- Building 3101 is a small, single-story building. One half of the building consists of a concrete block storage room, which remains locked to control access. The other half of the building is a covered concrete pad storage area. Both areas consist of approximately $100 \mathrm{sq} . \mathrm{ft}$.

- The building is located in an industrial area of the Main Plant at ORNL west of Building 3010 and Building 3080.

- Paint on exposed exterior surfaces of the building is in good condition.

- The immediate area surrounding Building 3101 is primarily paved.

- The interior portions of the building are not painted. Exterior painted surfaces are in fair to good condition. The building is not ventilated.

\section{Release Information}

Description of release, or threatened release, and source:

Small amounts of residual fixed radiologic (RAD) surface contamination exist in areas of the storage room of Building 3101 as a result of historical usage. This contamination has accumulated from storage activities involving a variety of equipment and materials throughout the operating history of the BSF and, therefore, cannot be attributed to a single release episode. The existing levels of RAD contamination in the building are reportedly very low. The presence of this contamination is not considered a significant hazard given its current state and the level of activity associated with the building.

Hazardous substances present:

Low levels of residual RAD surface contamination reportedly exist in areas of the storage room and some of the stored equipment.

No other hazardous substances were identified to be currently associated with Building 3101 . 
Estimate (if possible) of quantities of hazardous substances that have been released and that could be released:

No information regarding quantities of residual contamination within Building 3101 was identified during this RmSE.

Other pollutants or contaminants:

Based on the age of a facility, interior and exterior painted surfaces are assumed to be lead-containing. Verification samples are taken by ORNL Lead Management Program personnel on an "as-needed" basis to confirm the presence of lead in the paint (i.e., when work activities will disturb the paint, or paint is found to be deteriorating and poses a health or environmental threat). Interior surfaces of this building are not painted, and exterior painted surfaces were observed to be in fair to good condition, posing no immediate threat to human health or the environment.

\section{Groundwater}

Are there any suspected impacts to groundwater? If yes, please describe. Include any impacts to drinking water sources.

No evidence was identified during this RmSE to suggest that historical storage activities associated with Building 3101 have contributed to Waste Area Grouping (WAG) 1 groundwater contamination. Additionally, no existing immediate threat to groundwater was identified to be associated with this building.

\section{Surface Water}

Are there any suspected impacts to surface water? If yes, please describe. Also describe the most likely surface water migration route(s), if applicable. Include any impacts to drinking water sources.

WAG 1 is essentially bound by Fifth Creek to the east, White Oak Creek (WOC) to the south, and First Creek to the west. First and Fifth creeks flow south into WOC which flows to the west and exits WAG 1 at the southwest corner. Storm water (from surface runoff and storm water drainage system) and treated water from the process waste system discharges into WOC. The only apparent potential for historic or current impact to surface water from Building 3101 would be from lead-containing paint chips which may fall off the exterior painted surfaces and find their way into the storm water drainage system and eventually to WOC. This potential is considered to be slight given the current condition of the paint.

No other existing threats to surface water were identified to be associated with Building 3101 during this RmSE.

\section{Air}

Are there any suspected impacts due to air emissions? If yes, please describe.

Because of the reported low levels and small quantities of existing RAD contamination, it is not expected that catastrophic failure of the structure would result in significant impact to human health and the environment. Therefore, no significant threats to air quality were identified to be currently associated with Building 3101 during this RmSE. 


\section{Soil}

Are there any suspected impacts to soil? If yes, please describe.

The only existing potential threat to soils is the presence of assumed lead-based paint (LBP) on exterior surfaces of the building. Paint chips which fall off these surfaces have the potential to impact the soil below. Assumed LBP remaining on the exterior surfaces is in fair to good condition and not considered to be an immediate threat.

\section{Release Beyond Facility or Reservation Boundaries}

Has or will the release migrate beyond the boundaries of the facility or reservation? If yes, please describe (including possible human or environmental receptors).

The following are considered potential scenarios where radiologic contamination could migrate beyond the facility or reservation boundaries:

- A person becomes inadvertently contaminated from residual surface contamination and leaves the facility/reservation undetected.

There is also a potential for assumed lead-containing paint which peels off the building to be carried away from the facility and off-site with surface runoff during a rain event. Though these potentials exist, they are considered slight and unlikely due to the current status and condition of the facility and the administrative controls that are in place to protect again such an event.

\section{Worker Safety}

Could the release pose a threat to workers? If yes, please describe.

The storage room in Building 3101 is posted as a radiologically contaminated area. Good radiation practices and standard operating procedures governing activities involving the facility are enforced for worker safety. The storage room remains locked to control unauthorized access. However, even with these safeguards in place, a potential threat to workers exists if safety measures are overlooked. This potential is not considered significant given the current status and level of activity associated with this building.

\section{Environmental Receptors}

Does the release pose a potential threat to environmental receptors? If yes, please describe. Include natural resources impacts.

No existing conditions posing an immediate significant threat to environmental receptors, including natural resources, were identified to be currently associated with Building 3101 .

\section{Mitigation}

What action(s) might be taken to abate/prevent release or impacts from release?

- Continued utilization and enforcement of administrative controls that are currently in place to protect workers and monitor conditions and activities in the building. 
What actions are currently being taken to abate/prevent release or impacts from release?

Administrative controls are in place to control access to contaminated areas associated with Building 3101 and to monitor conditions and activities for worker and environmental protection. Standard operating procedures are in place for building access and $S \& M$ activities to protect against inadvertent contact and disturbance of contaminated areas and materials. The building remains in use for miscellaneous storage in support of BSF S\&M activities while awaiting entry into the Decontamination and Decommissioning (D\&D) Program.

Current actions being taken to prevent further release and ensure worker safety in Building 3101 are considered adequate until $D \& D$ activities begin.

\begin{tabular}{|l}
\hline \multicolumn{1}{|c|}{ Other Environmental Authorities } \\
\hline $\begin{array}{l}\text { Is the release or threatened release potentially subject to other environmental statutory actions? If yes, } \\
\text { please explain. }\end{array}$
\end{tabular}

If paint associated with the facility is found to be lead-containing and samples fail the Toxicity Characteristic Leaching Procedure (TCLP) analysis, the building could qualify as a hazardous waste generator point under the Resource Conservation and Recovery Act (RCRA).

\section{Maintenance Actions}

Are maintenance actions necessary to eliminate potential threats to human health and the environment? If so, explain.

No potential hazards requiring maintenance actions were identified to be associated with Building 3101 .

\section{Removal Actions}

Are Removal Actions necessary to eliminate immediate threat to human health and the environment? If so, explain.

No imminent hazards requiring removal actions per 40 CFR 300.415 were identified to be currently associated with Building 3101 .

\section{Remedial Site Evaluation}

Is a Remedial Site Evaluation needed?

Based on the age of the facility, painted surfaces are assumed to contain lead. Samples of the paint should be taken and analyzed to verify the presence of lead prior to conducting any S\&M or D\&D activities which may disturb these assumed areas.

\section{No Further Investigation}

Is a finding of No Further Investigation appropriate? Please explain.

A finding of No Further Investigation implies that a facility or area is free from hazardous substances or contaminants that may threaten human health and the environment. Since Building 3101 contains substances and materials which may become threatening if not properly controlled, handled and managed during the S\&M cycle, a finding of No Further Investigation is inappropriate in this case. 


\section{Additional Comments}

The following documents and databases were referenced for historical and hazard information related to Building 3101:

- Work Plan for the High Ranking Facilities Deactivation Project at Oak Ridge National Laboratory, Document No. ORNL/ER-322.

- Bulk Shielding Facility (BSF) Surveillance and Maintenance Work Plan, Document No. ORNL/RRD/INT-86/R1.

- Bulk Shielding Facility Shutdown Plan, Document No. ORNL/RRD/INT-84.

- Site Characterization Summary Report for Waste Area Grouping 1 at Oak Ridge National Laboratory, Oak Ridge Tennessee, Volumes 1 and 2, Document Nos. DOE/OR-1043/V1\&D1 and DOE/OR1043/V2\&D1

- ORNL Hazardous Material Information System Database.

- ORNL PCB Inventory Database.

- EM60 Surplus Facility Inventory and Assessment Database.

The following personnel and offices were contacted and provided historical and current use/condition information for Building 3101:

- Mr. R. D. Childs, Facility Manager, Bulk Shielding Facility.

- Ms. Swati Wilson, Manager, ORNL Lead Management Program.

- Mr. Nathan Dunn, Hazardous Material Information System Office.

- Mr. Jade Thomas, ORNL Environmental Compliance Office.

The RmSE of this facility was conducted for LMES under contract by:

Advanced Sciences, Inc.

800 Oak Ridge Turnpike, Suite C-102

Oak Ridge, TN

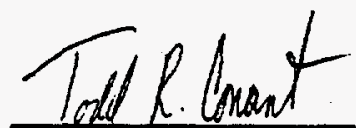

Evaluator's Signature 8/28/96 

9. BUILDING 3117 INFORMATION FORM 

ORNL FACILITY RmSE INFORMATION FORM

\begin{tabular}{|c|c|}
\hline \multicolumn{2}{|c|}{ General Information } \\
\hline \multicolumn{2}{|c|}{$\begin{array}{ll}\text { Area/Facility Name } & \\
\text { (and aliases): } & \text { Building } 3117 \text { (including Tank 3117A) } \\
& \text { Bulk Shielding Facility (BSF) Cooling Tower }\end{array}$} \\
\hline \multicolumn{2}{|c|}{$\begin{array}{ll}\text { Organization responsible for arealfacility } & \\
\text { (include specific person and phone number if possible): } & \text { K. Constant (241-3146), } \\
& \text { HRFDP Project Manager, } \\
& \text { ER Program, LMES }\end{array}$} \\
\hline $\begin{array}{c}\text { Status (active/inactive): Active (Cooling Tower) } \\
\text { Inactive (Tank) }\end{array}$ & Years of Operation: $\approx 33$ \\
\hline \multicolumn{2}{|c|}{$\begin{array}{l}\text { Description of Operation: } \\
\text { Building } 3117 \text { is a cooling tower which was historically used to support the reactor bay pool in Building } \\
3010 \text {. Tank } 3117 \mathrm{~A} \text { is an above ground, } 1,000 \text { gallon, stainless steel tank that was used to store sulfuric acid. } \\
\text { Currently, the tower continues to provide cooling water to BSF air conditioning units. The tank is no longer } \\
\text { in use and remains empty. }\end{array}$} \\
\hline \multicolumn{2}{|c|}{$\begin{array}{l}\text { Physical description of arealfacility: } \\
\text { - Building } 3117 \text { is a small single-story, wood-framed cooling tower consisting of approximately } 1,059 \\
\text { sq. ft. } \\
\text { - The tower is located in an industrial area of the Main Plant at ORNL east of Building } 3010 \text {. The tank } \\
\text { is located adjacent to the south side of the cooling tower and is diked for secondary containment. } \\
\text { - No painted surfaces were observed on the tower or the tank. } \\
\text { - The immediate area surrounding Building } 3117 \text { consists of both paving and grass. } \\
\text { - Tank piping has been disconnected, and the tank has been isolated. }\end{array}$} \\
\hline \multicolumn{2}{|c|}{ Release Information } \\
\hline \multicolumn{2}{|c|}{$\begin{array}{l}\text { There are reportedly no areas of radiologic contamination associated with this structure. Additionally, } \\
\text { no information regarding any adverse releases of hazardous substances associated with Building } 3117 \\
\text { or Tank } 3117 \text { A was identified during this RmSE. No current conditions were identified which present } \\
\text { an immediate potential for a significant release of any hazardous substance. }\end{array}$} \\
\hline $\begin{array}{l}\text { The only potential for significant release of hazardous su } \\
\text { Building } 3117 \text { would be the result of fire which could re } \\
\text { air and surrounding area in the form of ash and particulat } \\
\text { based on the current status, use, condition, and location c }\end{array}$ & $\begin{array}{l}\text { nces identified to be associated with } \\
\text { chemicals in the building materials to the } \\
\text { atter. This potential is considered slight } \\
\text { e cooling tower. }\end{array}$ \\
\hline
\end{tabular}


Hazardous substances present:

The wood framing of the tower has reportedly been treated with chromate which represents a potential hazard to human health if ingested or inhaled. Tank $3117 \mathrm{~A}$ is reportedly empty.

No other hazardous substances were identified to be currently associated with Building 3117 .

Estimate (if possible) of quantities of hazardous substances that hove been released and that could be released:

No information regarding the quantity of chromate associated with Building 3117 was identified during this RmSE.

Other pollutants or contaminants:

Asbestos containing material (ACM) is also associated with Building 3117 in the form of thermal system insulation and transite siding. ACM observed was in good condition and poses no immediate threat to human health or the environment.

\section{Groundwater}

Are there any suspected impacts to groundwater? If yes, please describe. Include any impacts to drinking water sources.

No evidence was identified during this RmSE to suggest that historical operation and usage of this cooling tower or tank has contributed to Waste Area Grouping (WAG) 1 groundwater contamination either radiologically or chemically. In addition, no existing immediate threat to groundwater was identified to be currently associated with this structure.

\section{Surface Water}

Are there any suspected impacts to surface water? If yes, please describe. Also describe the most likely surface water migration route(s), if applicable. Include any impacts to drinking water sources.

No evidence was identified during this RmSE to suggest that historical operation and usage of this cooling tower or tank has contributed to Waste Area Grouping (WAG) 1 surface water contamination either radiologically or chemically. In addition, no existing immediate threat to groundwater was identified to be currently associated with this structure.

\section{Air}

Are there any suspected impacts due to air emissions? If yes, please describe.

No evidence was identified during this RmSE to suggest that historical operation and usage of this cooling tower or tank has adversely impacted surrounding air quality. In addition, no immediate threats to air quality were identified to be currently associated with this structure.

There are, however, potentials for air quality impacts in the immediate area due to the chemical content and presence of asbestos in building materials used to construct the tower, should these materials burn or be improperly handled. Though these potentials exist, they are considered slight given the status, condition, and current use of the structure. 
Soil

Are there any suspected impacts to soil? If yes, please describe.

No evidence was identified during this RmSE to suggest that historical operation and usage of this cooling tower or tank has adversely impacted surrounding soil. In addition, no immediate threats to soils were identified to be currently associated with this structure.

\section{Release Beyond Facility or Reservation Boundaries}

Has or will the release migrate beyond the boundaries of the facility or reservation? If yes, please describe (including possible human or environmental receptors).

No historic or current adverse release of hazardous substances was identified to be associated with Building 3117 or Tank $3117 \mathrm{~A}$; therefore, there is no current threat of contaminant migration beyond facility or reservation boundaries.

\section{Worker Safety}

Could the release pose a threat to workers? If yes, please describe.

No existing conditions presenting an immediate threat to workers in the area of Building 3117 or $3117 \mathrm{~A}$ were identified during this RmSE. However, a potential threat to workers exists if safety measures and procedures are overlooked while conducting surveillance and maintenance (S\&M) activities involving asbestos containing, or chemically treated building materials. This potential is not considered significant given the current status and level of activity associated with the cooling tower.

\section{Environmental Receptors}

Does the release pose a potential threat to environmental receptors? If yes, please describe. Include natural resources impacts.

No existing conditions posing an immediate significant threat to environmental receptors, including natural resources, were identified to be currently associated with Building 3117 or Tank 3117A.

\section{Mitigation}

What action(s) might be taken to abate/prevent release or impacts from release?

- Continued utilization and enforcement of administrative controls that are currently in place to protect workers and monitor conditions and activities associated with Building 3117.

- Continue surveillance and maintenance (S\&M) activities per BSF Surveillance and Maintenance Work Plan, ORNL/RRD/INT-86/R1. 
What actions are currently being taken to abate/prevent release or impacts from release?

Administrative controls are in place to monitor conditions and activities associated with Building 3117 for worker and environmental protection. Standard operating procedures are in place for S\&M activities to protect against inadvertent contact and disturbance of hazardous building materials. The building remains in use providing cooling water to BSF air conditioners while awaiting entry into the Decontamination and Decommissioning (D\&D) Program. Tank 3117A is posted as being empty and inactive.

Current actions being taken to prevent an adverse release of hazardous substances and ensure worker safety in Buildings 3117 and Tank 3117A are considered adequate until D\&D activities begin.

\section{Other Environmental Authorities}

Is the release or threatened release potentially subject to other environmental statutory actions? If yes, please explain.

No release or threatened release potentially subject to other environmental statutory actions was identified to be currently associated with Building 3117 or Tank 3117A.

\section{Maintenance Actions}

Are maintenance actions necessary to eliminate potential threats to human health and the environment? If so, explain.

No potential hazards requiring maintenance actions were identified to be currently associated with Building 3117 or Tank 3117 A during this RmSE.

\section{Removal Actions}

Are Removal Actions necessary to eliminate immediate threat to human health and the environment? If so, explain.

No imminent hazards requiring removal actions per 40 CFR 300.415 were identified to be currently associated with Building 3117 or Tank $3117 \mathrm{~A}$ during this RmSE.

\section{Remedial Site Evaluation}

Is a Remedial Site Evaluation needed?

No existing conditions requiring a Remedial Site Evaluation (RSE) were identified to be currently associated with Building 3117 or Tank 3117A during this RmSE.

\section{No Further Investigation}

Is a finding of No Further Investigation appropriate? Please explain.

A finding of No Further Investigation implies that a facility or area is free from hazardous substances or contaminants that may threaten human health and the environment. Since Building 3117 contains substances and materials which may become threatening if not properly controlled, handled and managed during the S\&M cycle, and Tank 3117A may contain residual chemical contamination, a finding of No Further Investigation is inappropriate in this case. 


\section{Additional Comments}

The following documents and databases were referenced for historical and hazard information related to Building 3117 and Tank 3117A:

- Work Plan for the High Ranking Facilities Deactivation Project at Oak Ridge National Laboratory, Document No. ORNL/ER-322.

- Bulk Shielding Facility (BSF) Surveillance and Maintenance Work Plan, Document No. ORNL/RRD/INT-86/R1.

- Bulk Shielding Facility Shutdown Plan, Document No. ORNL/RRD/INT-84.

- Site Characterization Summary Report for Waste Area Grouping 1 at Oak Ridge National Laboratory, Oak Ridge Tennessee, Volumes 1 and 2, Document Nos. DOE/OR-1043/V1\&D1 and DOE/OR1043/V2\&D1

- ORNL Hazardous Material Information System Database.

- ORNL PCB Inventory Database.

- EM60 Surplus Facility Inventory and Assessment Database.

The following personnel and offices were contacted and provided historical and current use/condition information for Building 3117 and Tank 3117A:

- Mr. R. D. Childs, Facility Manager, Bulk Shielding Facility.

- Ms. Swati Wilson, Manager, ORNL Lead Management Program.

- Mr. Nathan Dunn, Hazardous Material Information System Office.

- Mr. Jade Thomas, ORNL Environmental Compliance Office.

The RmSE of this facility was conducted for LMES under contract by:

Advanced Sciences, Inc.

800 Oak Ridge Turnpike, Suite C-102

Oak Ridge, TN

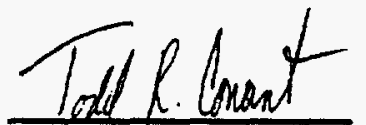

Evaluator's Signature 

10. BUILDING 3119 INFORMATION FORM 

ORNL FACILITY RmSE INFORMATION FORM

\begin{tabular}{|l|l|}
\hline \multicolumn{2}{|c|}{ General Information } \\
\hline $\begin{array}{l}\text { Area/Facility Name } \\
\text { (and aliases): }\end{array}$ & $\begin{array}{l}\text { Building } 3119 \\
\text { Bulk Shielding Reactor (BSR) Heat Exchanger and Pumphouse }\end{array}$ \\
\hline $\begin{array}{l}\text { Organization responsible for area/facility } \\
\text { (include specific person and phone number if possible): }\end{array}$ & $\begin{array}{l}\text { K. Constant (241-3146), } \\
\text { HRFDP Project Manager, } \\
\text { ER Program, LMES }\end{array}$ \\
\hline $\begin{array}{l}\text { Ytatus (active/inactive): } \\
\text { Inactive, Standby Mode }\end{array}$ & \\
\hline $\begin{array}{l}\text { Description of Operation: } \\
\text { There are no current operations, other than surveillance and maintenance (S\&M) activities, on-going in this } \\
\text { building. Building } 3119 \text { contains a heat exchanger and pumping equipment that was historically used to } \\
\text { support the reactor bay pool cooling system. }\end{array}$
\end{tabular}

Physical description of arealfacility:

- Building 3119 is a small, single-room, concrete block structure which consists of approximately 667 sq. $\mathrm{ft}$. of floor space.

- The building is located in an industrial area of the Main Plant at ORNL east of Building 3010.

- Paint on exterior surfaces of the building is in good condition.

- The immediate area surrounding Building 3010 is mostly paved with some grassy areas to the south.

- The interior of the building is in fair to good condition. Asbestos containing material (ACM) and radiation (RAD) hazard areas are posted and/or labeled as appropriate. Painted surfaces are in good with some localized areas of minor deterioration.

- The building contains one 100-gallon caustic tank and one 100-gallon nitric acid tank which are both reportedly empty and clean.

\section{Release Information}

Description of release, or threatened release, and source:

Low levels of residual fixed radiologic surface contamination exist in areas of the building as a result of historical operations. The contamination is associated primarily with the process equipment (piping, pumps, heat exchanger, etc.). This contamination has accumulated from activities throughout the operating history of the BSF and, therefore, cannot be attributed to a single release episode. The existing levels of RAD contamination in the building are reportedly low and the presence of this contamination is not considered a significant hazard in its current state.

Hazardous materials (HAZMATs) (e.g., acids, caustics) were reportedly used in large quantities (i.e., greater than 5 gallons or 100 pounds) during facility operations. According to available spill/release records and facility personnel interviews, no significant HAZMAT spills (i.e., spills having the potential to adversely affect human health and/or the environment) have been reported for this building. All HAZMATs have been removed from the building; therefore, no current conditions were identified which present a potential for a significant HAZMAT release. 
Hazardous substances present:

Hazardous substances remaining in Building 3119 consist mainly of residual RAD surface contamination. Areas of fixed RAD contamination are associated primarily with process equipment. Reportedly, there are also some random areas of fixed surface contamination on walls, floors, and drains.

Estimate (if possible) of quantities of hazardous substances that have been released and that could be released:

No information regarding quantities of hazardous substances existing in Building 3119 was identified during this RmSE. Based on the residual nature of the contamination reportedly present, it is expected that the quantities are small.

Other pollutants or contaminants:

Asbestos containing material, primarily in the form of thermal system insulation, has been confirmed present in this building. ACM observed is in good condition and poses no immediate health threat. Based on the age of the facility, interior and exterior painted surfaces are assumed to be lead-containing. Verification samples are taken by ORNL Lead Management Program personnel on an "as-needed" basis to confirm the presence of lead in the paint (i.e., when work activities will disturb the paint, or paint is found to be deteriorating and poses a health or environmental threat). Interior painted surfaces observed are in fair to good condition. Paint on exterior surfaces is in good condition.

\section{Groundwater}

Are there any suspected impacts to groundwater? If yes, please describe. Include any impacts to drinking water sources.

Building 3119 is located in Waste Area Grouping 1 at ORNL. Although no specific adverse spills or releases of hazardous substances were identified during this RmSE, it is suspected, based on available environmental studies conducted in WAG 1, that process waste drains and associated piping may have leaked over the life of the building. (Reportedly, the building has no low-level liquid waste (LLLW) service.) Buried process and LLLW piping and some drains have been found to be deteriorated and leaking in other facilities and areas of WAG 1. Studies have determined that groundwater in WAG 1 has been both radiologically and chemically contaminated. Because of the age and nature of operations in this building, it is possible that liquid waste from processes involving chemicals and radioisotopes in Building 3119 have historically contributed to WAG 1 groundwater contamination. However, the radionuclides and chemicals detected in the groundwater were common to the processes and activities in many other buildings in the area which makes it difficult to determine exactly which building is, or was, the source of contamination.

Other than the potential for historical impact to groundwater in WAG 1 via leaking process waste lines external to the building, no existing immediate threat to groundwater was identified given the current status of the facility. 


\section{Surface Water}

Are there any suspected impacts to surface water? If yes, please describe. Also describe the most likely surface water migration route(s), if applicable. Include any impacts to drinking water sources.

WAG 1 is essentially bound by Fifth Creek to the east, White Oak Creek (WOC) to the south, and First Creek to the west. First and Fifth creeks flow south into WOC which flows to the west and exits WAG 1 at the southwest comer.

Storm water (from surface runoff and storm water drainage system) and treated water from the process waste system discharges into WOC. The only potential for direct impact to surface water from Building 3119 in its current state would be from lead-containing paint chips which fall off the exterior painted surfaces and find their way into the storm water drainage system and eventually to WOC.

Surface water may have also been indirectly impacted by leaking process waste lines external to the building. Some of these lines are known to have shared a common trench with storm water drainage piping. Contamination from leaking waste lines could potentially enter deteriorated storm water piping and migrate to WOC. The three creeks bordering WAG 1 are groundwater discharge points. Therefore, groundwater contaminated by leaking waste lines could also potentially impact surface water in the area.

Other than the potential for historical impact, no existing immediate threats to surface water were identified to be associated with this building.

\section{Air}

Are there any suspected impacts due to air emissions? If yes, please describe.

Because of the presence of residual contamination within the building, a potential exists for radiation exposure to personnel working inside and within the immediate vicinity of the building due to potential airborne migration of radioactive particulates and physical contact with contaminated surfaces. Areas of RAD contamination are identified, marked, and controlled as appropriate throughout the building to protect against inadvertent exposure to personnel. Building 3119 is not serviced by a ventilation system and remains at atmospheric pressure. Apart from catastrophic failure of the structure or contaminated equipment, it is unlikely that radioactive air emissions from Building 3119 would impact personnel or the environment in its current state.

A potential also exists for impact to indoor air quality due to the presence of $\mathrm{ACM}$ and assumed lead-based paint (LBP) should these materials be disturbed. The ACM and assumed LBP remaining in the building are not considered to be immediate threats to indoor quality in their current state.

\section{Soil}

Are there any suspected impacts to soil? If yes, please describe.

As stated for groundwater, there is a potential for historical impact to soils in the area of Building 3119 due to leaking process waste drains and piping. Previous environmental studies have identified areas of soil contamination throughout WAG 1 and soil samples collected have detected radioisotopes and chemicals common to the processes performed in this building and surrounding BSF support buildings. Since, these chemicals and radioisotopes were common to the processes in many of the other buildings in the area, it is difficult to determine whether waste from Building 3119 operations has actually contributed to WAG 1 soil contamination based on the information reviewed during this RmSE. 
Are there any suspected impacts to soil? If yes, please describe. (Continued)

There is also a potential for areas of soil adjacent to the facility to be impacted from lead if, in fact, exterior paint is found to be lead-containing. Deteriorating paint could dislodge from the surface and fall to the soil below. The exterior paint was observed to be good condition and does not pose an immediate threat in its current state.

Release Beyond Facility or Reservation Boundaries

Has or will the release migrate beyond the boundaries of the facility or reservation? If yes, please describe (including possible human or environmental receptors).

The following are considered potential scenarios where radiologic contamination could migrate beyond the facility or reservation boundaries:

- A person becomes inadvertently contaminated from residual surface contamination and leaves the facility/reservation undetected.

- Catastrophic failure of the building or contaminated equipment.

There is also a potential for assumed lead-containing paint which peels off of the building to be carried away with surface runoff during a rain event. Though these potentials exist, they are considered slight and unlikely due to the current status of the facility and the engineering/administrative controls that are in place to protect again such an event.

\section{Worker Safety}

Could the release pose a threat to workers? If yes, please describe.

Radiologically contaminated areas are isolated and well marked. Good radiation practices and standard operating procedures are enforced for worker safety. Access to the building is controlled. Personnel exiting the building are required to "frisk" themselves to detect the presence of RAD contamination. Asbestos containing material remaining in the building is appropriately labeled. However, even with these safeguards in place, a potential threat to workers exists if safety measures are overlooked. This potential is not considered significant given the current status and level of activity of the building.

\section{Environmental Receptors}

Does the release pose a potential threat to environmental receptors? If yes, please describe. Include natural resources impacts.

No existing conditions posing an immediate significant threat to environmental receptors, including natural resources, were identified to be currently associated with Building 3119 .

\section{Mitigation}

What action(s) might be taken to abate/prevent release or impacts from release?

- Continued utilization and enforcement of engineering and administrative controls that are currently in place to protect workers and monitor conditions and activities in the building.

- Continue S\&M activities per BSF Surveillance and Maintenance Work Plan, ORNL/RRD/INT-86/R1. 
What actions are currently being taken to abate/prevent release or impacts from release?

Engineering and administrative controls are in place to control access to the facility and contaminated areas, and to monitor conditions and activities within the facility for worker and environmental protection. Warning signs and labels are posted within the building indicating RAD and ACM hazard areas. Standard operating procedures are in place for building access and S\&M activities to protect against inadvertent contact and disturbance of contaminated areas and materials. Radiologically contaminated areas are monitored periodically by ORNL health physics personnel.

Personnel are "frisked" upon exit of the building to detect the presence of radiologic contamination. The building is currently deactivated and in S\&M status awaiting entry into the Decontamination and Decommissioning (D\&D) Program. The electrical system remains operational to support current activities within the building. The building is inspected periodically for structural changes and degradation which include any cracking, failure, or deterioration of the facility and/or equipment that may allow contamination to be released.

Current actions being taken to prevent further release and ensure worker safety in Building 3119 are considered adequate until $\mathrm{D} \& \mathrm{D}$ activities begin.

\section{Other Environmental Authorities}

Is the release or threatened release potentially subject to other environmental statutory actions? If yes, please explain.

If paint associated with the facility is found to be lead-containing and samples fail the Toxicity Characteristic Leaching Procedure (TCLP) analysis, the building could qualify as a hazardous waste generator point under the Resource Conservation and Recovery Act (RCRA).

\section{Maintenance Actions}

Are maintenance actions necessary to eliminate potential threats to human health and the environment? If so, explain.

No potential hazards requiring maintenance actions were identified to be associated with Building 3119 .

\section{Removal Actions}

Are Removal Actions necessary to eliminate immediate threat to human health and the environment? If so, explain.

No imminent hazards requiring removal actions per 40 CFR 300.415 were identified to be currently associated with Building 3119.

\section{Remedial Site Evaluation}

Is a Remedial Site Evaluation needed?

Areas of radiologic contamination associated with Building 3119 have been identified and marked as appropriate. However, it is suspected that process and LLLW drains and associated piping may have leaked in the BSF area; therefore, the soil beneath the slab of the building may be contaminated. As a result, it is recommended that some type of remedial investigation be performed to assess the condition of the soil in this area before conducting any S\&M or D\&D activities which involve disturbing the slab. 
Is a Remedial Site Evaluation needed? (Continued)

Asbestos containing materials have also been identified, marked and documented. No further remedial investigation involving these hazards is considered necessary given the current status and future plans of this building.

Based on the age of the facility, painted surfaces are assumed to contain lead. Samples of the paint should be taken and analyzed to verify the presence of lead prior to conducting any S\&M or D\&D activities which may disturb these assumed areas.

\section{No Further Investigation}

Is a finding of No Further Investigation appropriate? Please explain.

A finding of No Further Investigation implies that a facility or area is free from hazardous substances or contaminants that may threaten human health and the environment. Since Building 3119 contains substances and materials which may become threatening if not properly controlled, handled and managed during the S\&M cycle, a finding of No Further Investigation is inappropriate in this case.

\section{Additional Comments}

The following documents and databases were referenced for historical and hazard information related to Building 3119:

- Work Plan for the High Ranking Facilities Deactivation Project at Oak Ridge National Laboratory, Document No. ORNL/ER-322.

- Bulk Shielding Facility (BSF) Surveillance and Maintenance Work Plan, Document No. ORNL/RRD/INT-86/R1.

- Bulk Shielding Facility Shutdown Plan, Document No. ORNL/RRD/INT-84.

- Site Characterization Summary Report for Waste Area Grouping 1 at Oak Ridge National Laboratory, Oak Ridge Tennessee, Volumes 1 and 2, Document Nos. DOE/OR-1043/VI\&DI and DOE/OR1043/V2\&D1

- ORNL Hazardous Material Information System Database.

- ORNL PCB Inventory Database.

- EM60 Surplus Facility Inventory and Assessment Database.

The following personnel and offices were contacted and provided historical and current use/condition information for Building 3119 :

- Mr. R. D. Childs, Facility Manager, Bulk Shielding Facility.

- Ms. Swati Wilson, Manager, ORNL Lead Management Program.

- Mr. Nathan Dunn, Hazardous Material Information System Office.

- Mr. Jade Thomas, ORNL Environmental Compliance Office.

The RmSE of this facility was conducted for LMES under contract by:

Advanced Sciences, Inc.

800 Oak Ridge Turnpike, Suite C-102

Oak Ridge, TN

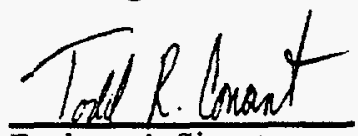

Evaluator's Signature 
11. Tanks A-1204 and 13822 INFORMATION FORM 


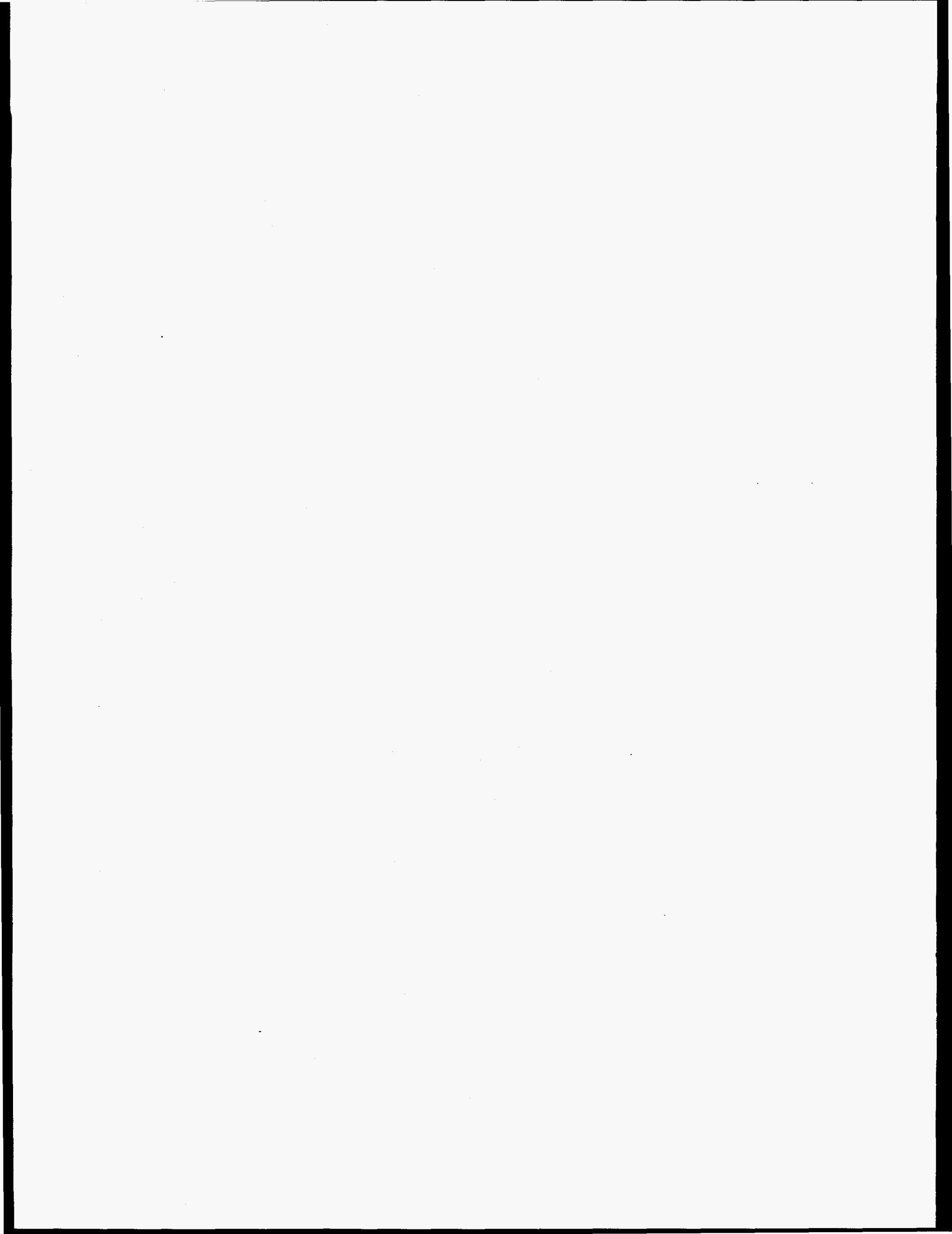


ORNL FACILITY RmSE INFORMATION FORM

\begin{tabular}{|c|c|c|}
\hline \multicolumn{3}{|c|}{ General Information } \\
\hline $\begin{array}{l}\text { Area/Facility Name } \\
\text { (and aliases): }\end{array}$ & \multicolumn{2}{|c|}{$\begin{array}{l}\text { Tanks A-1204 and } 13822 \\
\text { Low Temperature Neutron Irradiation Facility (LTNIF) refrigerant tanks }\end{array}$} \\
\hline \multicolumn{3}{|c|}{$\begin{array}{ll}\text { Organization responsible for area/facility } & \\
\text { (include specific person and phone number if possible): } & \text { K. Constant (241-3146), } \\
& \text { HRFDP Project Manager, } \\
& \text { ER Program, LMES }\end{array}$} \\
\hline Status (active/inactive): & Inactive, Standby Mode & Years of Operation: $\approx 3$ \\
\hline \multicolumn{3}{|c|}{$\begin{array}{l}\text { Description of Operation: } \\
\text { These two cryogenic tanks were historically used to provide liquid nitrogen and liquid helium to the LTNIF } \\
\text { refrigeration unit in the south annex of the Bulk Shielding Facility (BSF) during LTNIF operations. } \\
\text { Currently, all LTNIF equipment housed in the south annex has been removed from the BSF and these tanks } \\
\text { remain empty and out of service. }\end{array}$} \\
\hline \multicolumn{3}{|c|}{$\begin{array}{l}\text { Physical description of area/facility: } \\
\text { - Tank A-1204 is a } 500 \text { gallon, above ground cryogenic tank that was used to store liquid nitrogen. Tank } \\
13822 \text { is a } 700 \text { gallon, above ground cryogenic tank adjacent to Tank A-1204 that was used to store } \\
\text { liquid helium. } \\
\text { - These tanks are located in an industrial area of the Main Plant at ORNL adjacent to the west side of } \\
\text { Building } 3010 \text {. } \\
\text { - Paint on exterior surfaces of the tanks is in good condition. } \\
\text { - The immediate area surrounding these tanks is paved. } \\
\text { - These tanks are reportedly empty and believed to be internally clean. }\end{array}$} \\
\hline \multicolumn{3}{|c|}{ Release Information } \\
\hline \multicolumn{3}{|c|}{$\begin{array}{l}\text { Description of release, or threatened release, and source: } \\
\text { No evidence was identified during this RmSE to suggest that there have been any adverse releases } \\
\text { associated with either these tanks. Additionally, no potential for an adverse release was found to be } \\
\text { currently associated with either of these tanks. }\end{array}$} \\
\hline \multicolumn{3}{|c|}{ Hazardous substances present: } \\
\hline \multicolumn{3}{|c|}{$\begin{array}{l}\text { No hazardous substances were identified to be currently associated with either of these tanks during this } \\
\text { RmSE. }\end{array}$} \\
\hline \multicolumn{3}{|c|}{$\begin{array}{l}\text { Estimate (if possible) of quantities of hazardous substances that have been released and that could be } \\
\text { released: } \\
\text { No hazardous substances were identified to be currently associated with either of these tanks during this } \\
\text { RmSE. }\end{array}$} \\
\hline
\end{tabular}


Other pollutants or contaminants:

No other pollutants or contaminants were found to be associated with either of these tanks during this RmSE. Based on the age of these tanks (13822 was installed in 1985 and A-1204 in 1984) it is unlikely that the exterior paint on these tanks contains lead; however, this cannot be verified without chemical analysis.

\section{Groundwater}

Are there any suspected impacts to groundwater? If yes, please describe. Include any impacts to drinking water sources.

No evidence was identified during this RmSE to suggest that historical usage of these tanks has contributed to Waste Area Grouping (WAG) 1 groundwater contamination. In addition, no existing threat to groundwater was identified to be currently associated with these tanks.

\section{Surface Water}

Are there any suspected impacts to surface water? If yes, please describe. Also describe the most likely surface water migration route(s), if applicable. Include any impacts to drinking water sources.

No evidence was identified during this RmSE to suggest that historical usage of these tanks has contributed to Waste Area Grouping (WAG) 1 surface water contamination. In addition, no existing threat to surface water was identified to be currently associated with these tanks.

Air

Are there any suspected impacts due to air emissions? If yes, please describe.

No evidence was identified during this RmSE to suggest that historical usage of these tanks has impacted air quality. In addition, no existing threat to air quality was identified to be currently associated with these tanks.

\section{Soil}

Are there any suspected impacts to soil? If yes, please describe.

No evidence was identified during this RmSE to suggest that historical usage of these tanks has contributed to Waste Area Grouping (WAG) 1 soil contamination. In addition, no existing threat to soils in the area was identified to be currently associated with these tanks.

Release Beyond Facility or Reservation Boundaries

Has or will the release migrate beyond the boundaries of the facility or reservation? If yes, please describe (including possible human or environmental receptors).

No potential for adverse release of hazardous substances beyond the facility or reservation boundaries was identified to be currently associated with these tanks during this RmSE. 


\section{Worker Safety}

Could the release pose a threat to workers? If yes, please describe.

No potential for release of hazardous substances threatening worker safety was identified to be currently associated with these tanks.

\section{Environmental Receptors}

Does the release pose a potential threat to environmental receptors? If yes, please describe. Include natural resources impacts.

No existing conditions posing a threat to environmental receptors, including natural resources, were identified to be currently associated with these tanks.

\section{Mitigation}

What action(s) might be taken to abate/prevent release or impacts from release?

No conditions presenting a potential for adverse release or impact from release were identified to be currently associated with these tanks. The tanks are empty and represent no apparent hazard in their current state. Therefore, no mitigation actions are considered to be required to maintain the tanks in a safe state.

What actions are currently being taken to abate/prevent release or impacts from release?

These tanks contain no hazardous substances and present no threat of adverse release given their current condition. Reportedly, no surveillance and maintenance (S\&M) actions are required to maintain these tanks in a safe state.

Other Environmental Authorities

Is the release or threatened release potentially subject to other environmental statutory actions? If yes, please explain.

No release or threatened release subject to any environmental statutory actions were identified to be currently associated with these tanks during this RmSE.

\section{Maintenance Actions}

Are maintenance actions necessary to eliminate potential threats to human health and the environment? If so, explain.

No potential hazards requiring maintenance actions were identified to be associated with these tanks.

\section{Removal Actions}

Are Removal Actions necessary to eliminate immediate threat to human health and the environment? If so, explain.

No imminent hazards requiring removal actions per 40 CFR 300.415 were identified to be currently associated with these tanks. 


\section{Remedial Site Evaluation}

Is a Remedial Site Evaluation needed?

No existing conditions requiring a Remedial Site Evaluation (RSE) were identified to be currently associated with these tanks.

\section{No Further Investigation}

Is a finding of No Further Investigation appropriate? Please explain.

A finding of No Further Investigation implies that a facility or area is free from hazardous substances or contaminants that may threaten human health and the environment. Based on the information reviewed during this RmSE in regard to past usage and current condition of these tanks, and subsequent visual inspection, no reasonable evidence was identified to suggest that these tanks represent an existing our potential threat to human health and/or the environment. Therefore, it is recommended that verification samples be taken to ensure the paint on the tanks is lead-free and a No Further Investigation Determination be pursued for Tank 13822 and Tank A-1204 in accordance with the guidelines set forth in ES/ER/TM-161, Rev. 0, "Site Evaluation Process for the DOE-ORO Environmental Restoration Program" pending sample results.

\section{Additional Comments}

The following documents and databases were referenced for historical and hazard information related to Tanks 13822 and A-1204:

- Work Plan for the High Ranking Facilities Deactivation Project at Oak Ridge National Laboratory, Document No. ORNL/ER-322.

- Bulk Shielding Facility (BSF) Surveillance and Maintenance Work Plan, Document No. ORNL/RRD/INT-86/R1.

- Bulk Shielding Facility Shutdown Plan, Document No. ORNL/RRD/TNT-84.

- Site Characterization Summary Report for Waste Area Grouping 1 at Oak Ridge National Laboratory, Oak Ridge Tennessee, Volumes 1 and 2, Document Nos. DOE/OR-1043/V1\&D1 and DOE/OR1043/V2\&D1

- ORNL Hazardous Material Information System Database.

- ORNL PCB Inventory Database.

- EM60 Surplus Facility Inventory and Assessment Database.

The following personnel and offices were contacted and provided historical and current use/condition information for Tanks 13822 and A-1204:

- Mr. R. D. Childs, Facility Manager, Bulk Shielding Facility.

- Ms. Swati Wilson, Manager, ORNL Lead Management Program.

- Mr. Nathan Dunn, Hazardous Material Information System Office.

- Mr. Jade Thomas, ORNL Environmental Compliance Office.

The RmSE of this facility was conducted for LMES under contract by:

Advanced Sciences, Inc.

800 Oak Ridge Turnpike, Suite C-102

Oak Ridge, TN

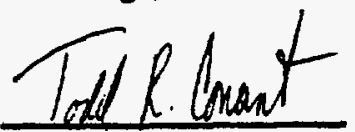

Evaluator's Signature 


\section{DISTRIBUTION}

1. L. V. Asplund

2. T. W. Burwinkle

3. K. W. Cook

4. R. E. Eversole

5. L. L. Kaiser

6-8. D. M. Matteo (3)

9. P. T. Owen

10. L. D. Owens

11. P. A. Schrandt

12. Central Research Library

13. ER Central Doc. Mgmt. Center-RC

14. R. L. Nace, Team Leader, Fernald/Ohio Team, Office of Environmental Restoration, U.S. Department of Energy, Cloverleaf Building, EM-425, 19901 Germantown Road, Germantown, MD 20874

15. J. W. Wagoner II, Team Leader, Portsmouth/Paducah/Weldon Spring Team, Office of Environmental Restoration, U.S. Department of Energy, Cloverleaf Building, EM-424, 19901 Germantown Road, Germantown, MD 20874

16. V. F. Boston, DOE Oak Ridge Operations Office, P.O. Box 2001, Oak Ridge, TN 37831-8541

17-18. R. C. Sleeman, Director, Environmental Restoration Division, DOE Oak Ridge Operations Office, P.O. Box 2001, Oak Ridge, TN 37831-8541 (2)

19-20. Office of Scientific and Technical Information, P.O. Box 62, Oak Ridge, TN 37831 (2)

21. T. R. Conant, Advanced Sciences, Inc., 800 Oak Ridge Turnpike, Suite C-102, Oak Ridge, TN 37830-6927 